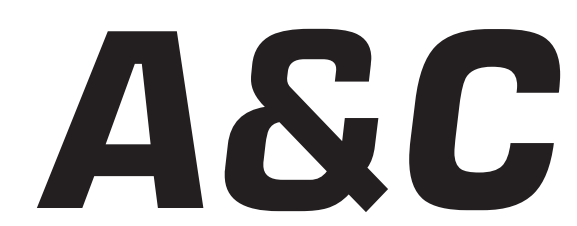

Revista de Direito Administrativo \& Constitucional

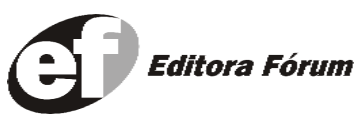

A\&C R. de Dir. Administrativo e Constitucional, Belo Horizonte, ano 5, n.19, p. 1-254, jan./mar. 2005 


\section{A\&C REVISTA DE DIREITO ADMINISTRATIVO E CONSTITUCIONAL}

\section{IPDA}

Instituto Paranaense

de Direito Administrativo

Direção Geral

Romeu Felipe Bacellar Filho

Direção Editorial

Paulo Roberto Ferreira Motta

Direção Executiva

Emerson Gabardo

Conselho de Redação

Edgar Chiuratto Guimarães

Adriana da Costa Ricardo Schier

Célio Heitor Guimarães

Conselho Editorial

Adilson Abreu Dallari

Alice Gonzáles Borges

Carlos Ari Sundfeld

Carlos Ayres Britto

Carlos Delpiazzo

Cármen Lúcia Antunes Rocha

Celso Antônio Bandeira de Mello

Clèmerson Merlin Clève

Clóvis Beznos

Enrique Silva Cimma

Eros Roberto Grau

Fabrício Motta

Guilhermo Andrés Muñoz (in memoriam)

Jaime Rodríguez-Arana Muñoz

Jorge Luís Salomoni
José Carlos Abraão
José Eduardo Martins Cardoso

José Luís Said

José Mario Serrate Paz

Juan Pablo Cajarville Peruffo

Juarez Freitas

Julio Rodolfo Comadira

Luís Enrique Chase Plate

Lúcia Valle Figueiredo

Manoel de Oliveira Franco Sobrinho

(in memoriam)

Marçal Justen Filho

Marcelo Figueiredo

Márcio Cammarosano

Maria Cristina Cesar de Oliveira
Nelson Figueiredo

Odilon Borges Junior

Pascual Caiella

Paulo Eduardo Garrido Modesto

Paulo Henrique Blasi

Paulo Neves de Carvalho (in memoriam)

Paulo Ricardo Schier

Pedro Paulo de Almeida Dutra

Regina Maria Macedo Nery Ferrari

Rogério Gesta Leal

Rolando Pantoja Bauzá

Sérgio Ferraz

Valmir Pontes Filho

Yara Stropa

Weida Zancaner

\footnotetext{
A246 A\&C Revista de Direito Administrativo e Constitucional. ano 3, n. 11, jan./mar. 2003. Belo Horizonte: Fórum, 2003.

Trimestral

ano 1, n.1, 1999 até ano 2, n.10, 2002 publicada pela Editora Juruá em Curitiba

ISSN: 1516-3210

1. Direito Administrativo. 2. Direito Constitucional. I. Fórum.
}

CDD: 342 CDU: 33.342

(c) Editora Fórum Ltda. 2005

Todos os direitos reservados. É proibida a reprodução total ou parcial, de qualquer forma ou por qualquer meio eletrônico ou mecânico, inclusive através de processos xerográficos, de fotocópias ou de gravação, sem permissão por escrito do possuidor dos direitos de cópias (Lei $n^{\circ}$ 9.610, de 19.02.1998).

Editora Fórum Ltda

Av. Afonso Pena, 2770 - 15\%16ªndar - Funcionários

CEP 30130-007 - Belo Horizonte/MG - Brasil

Tel.: 08007043737

Internet: www.editoraforum.com.br

e-mail: editoraforum@editoraforum.com.br
Editor responsável: Luís Cláudio Rodrigues Ferreira Projeto gráfico e diagramação: Luis Alberto Pimenta Revisora: Olga M. A. Sousa

Pesquisa jurídica: Fátima Ribeiro - OAB/MG 74868

Bibliotecária: Nilcéia Lage de Medeiros

CRB 1545/MG 6a região

Os conceitos e opiniões expressas nos trabalhos assinados são de responsabilidade exclusiva de seus autores.

Impressa no Brasil / Printed in Brazil

Distribuída em todo Território Nacional 


\title{
Aposentadoria dos Servidores Públicos Federais após as Reformas da Constituição
}

\author{
Mauro Roberto Gomes de Mattos \\ Advogado no Rio de Janeiro. Autor dos livros O Contrato Administrativo e O Limite da Improbi- \\ dade Administrativa - O Direito dos Administrados dentro da Lei $n^{\circ}$ 8.429/92. Vice-Presidente \\ do Instituto Ibero Americano de Direito Público - IADP. Membro da Sociedade Latino-Americana \\ de Direito do Trabalho e Seguridade Social. Membro do IFA - Internacional Fiscal Association. \\ Conselheiro efetivo da Sociedade Latino-Americana de Direito do Trabalho e Seguridade Social
}

Sumário: I Alterações constitucionais e a Emenda $n^{\circ}$ 41/2003 - II Regra de transição da aposentadoria voluntária - III Cálculo dos valores a serem pagos na aposentadoria - IV Do art. 186, da Lei $n^{\circ} 8.112 / 90$ e a Emenda Constitucional no 41/2003 - V Da Lei no 10.887 , de 18 de junho de 2004 - VI Da aposentadoria por invalidez - VII Emenda Constitucional no $41 / 2003$ e o respeito aos direitos adquiridos - VIII Principais mudanças na PEC Paralela - Proposta de Emenda à Constituição no 227-A, de 2004

\section{Alterações constitucionais e a Emenda n 41/2003}

No curso dos anos a Constituição vem sendo emendada para tentar sanar os problemas financeiros da Previdência Social. Sucessivamente, é afirmado pelos maiores escalóes da República que a Previdência Social no Brasil é uma instituição carente financeiramente, apesar de gerir um dos maiores orçamentos do país. Esse insucesso é atribuído à falta de planejamento dos governantes passados, que ao se depararem com um estoque jovem de contribuintes não se preocuparam em blindar o sistema contra futuros déficits atuariais. Todavia, esse mal ou deficiente planejamento não poderá ser debitado na conta de quem não deu azo às gestões financeiras incompetentes e simplesmente figura na relação jurídica como segurado. Assim, o Executivo, vem no curso dos anos alterando as normas previdenciárias com o objetivo de tornar o sistema de previdência mais atrativo, incluindo em seu contexto os servidores públicos.

A redação embrionária do art. 40, da CF era explícita em garantir a aposentadoria do servidor nas seguintes situações jurídicas:

Art. 40. O servidor será aposentado: I - por invalidez permanente, sendo os proventos integrais quando decorrentes de acidente em serviço, moléstia profissional ou doença grave, contagiosa ou incurável, especificadas em lei, e proporcionais nos demais casos; II - compulsoriamente, aos 70 anos de idade, com proventos proporcionais ao tempo de serviço; III - voluntariamente: a) aos 35 anos de serviço, se homem, e aos 30 se mulher, com proventos integrais; 
b) aos 30 anos de efetivo exercício em funções de magistério, se professor, em 25 anos, se professora, com proventos integrais; c) aos 30 anos de serviço, se homem, e aos 25 se mulher, com proventos proporcionais a esse tempo; $d$ ) aos 60 se mulher, com proventos proporcionais ao tempo de serviço.

A redação originária do art. 40, da CF, como visto, era a da aposentadoria por tempo de serviço, por invalidez e a compulsória, vinculada a uma regra de paridade entre os proventos com os vencimentos recebidos no cargo ativo (art. $40, \S 4^{\circ}$ da $\mathrm{CF}$ ).

Bastava ao servidor público adquirir o tempo de serviço mínimo, que ele estaria apto para ser destinatário do direito a se aposentar pela regra pré-determinada pela $\mathrm{CF}$, recebendo proventos da aposentadoria com base no cargo efetivo de igual nomenclatura, como se não houvesse a interrupção na carreira. Dessa forma, reposicionamento, gratificação, aumento de estipêndios e qualquer outra vantagem, pela regra então baixada, em 5.10.1988, prevista no art. $40, \S 4^{\circ}$, da CF, era extensivo ao servidor aposentado, acabando a regra do art. 102, da CF de 1969, que impedia que o aposentado recebesse mais na inatividade do que na atividade. Essa paridade do inativo com o servidor ativo foi fruto de muito sacrifício, onde o servidor inativo havia se transformado em um pária da sociedade, com desrespeito ao seu passado, pois os anos corroíam os seus proventos sem que houvesse uma justa recomposição. A então, nova Constituição trouxe a fórmula do $\S 4^{\circ}$ do art. 40, como uma tábua de salvação dos estipêndios dos aposentados, que sofriam reajustes e evoluções compassados com os servidores paradigmas em atividade.

Com a vinda da Emenda Constitucional no 20, de 15.12.1998, houve substancial alteração da redação original do art. 40 da CF, que deixou a aposentadoria de ser por tempo de serviço para se encaixar em um regime de previdência de caráter contributivo, observado critérios que "preservem o equilíbrio financeiro e atuarial e o disposto neste artigo".

Pela regra da EC no 20/98, a aposentadoria dos servidores públicos passou a ser de caráter contributivo, observando-se critérios que preservem o equilíbrio financeiro e atuarial, com a participação do ente público, responsável por aportes financeiros.

Sobre o que foi dito assim se posiciona Odete Medauar: ${ }^{1}$

O regime de caráter contributivo é aquele em que há contribuição direta do servidor para que este tenha direito à aposentadoria. Além disso, há também o aporte de recursos do respectivo ente estatal. Com o objetivo de assegurar re${ }^{1}$ MEDAUAR, Odete. Direito Administrativo Moderno. Revista dos Tribunais, 2004, p. 335.

A \& C R. de Dir. Administrativo e Constitucional, Belo Horizonte, ano 5, n. 19, p. 161-199, jan./mar. 2005 
cursos para o pagamento dos proventos de aposentadoria e pensões concedidas aos respectivos servidores e dependentes, em adição aos recursos dos respectivos tesouros, a União, os Estados, o Distrito Federal e os Municípios poderão construir fundos integrados pelos recursos provenientes de contribuições e por bens, direitos e ativos de qualquer natureza, mediante lei, que disporá sobre a natureza e administração desse fundo (art. 249 das Disposições Constitucionais Gerais, acrescentado pela Emenda Constitucional no 20/98).

Por essa regra constitucional, foram incluídos os membros do Poder Judiciário, do Ministério Público e dos Tribunais de Contas no regime geral de previdência social, além dos servidores públicos da administração direta e indireta da União Federal, dos Municípios, dos Estados e do Distrito Federal, tendo as seguintes características:

- por invalidez permanente, sendo os proventos proporcionais ao tempo de contribuição, exceto se decorrente de acidente em serviço, moléstia profissional ou doença grave, contagiosa ou incurável, especificados em lei;

- compulsoriamente, aos 70 anos de idade, com proventos proporcionais ao tempo de contribuição do servidor;

- voluntariamente, desde que cumprido o tempo mínimo de 10 anos de efetiva prestação de serviços ao ente público e cinco anos no cargo efetivo em que se dará a aposentadoria, variando a regra para o homem e a mulher. Se homem, ele terá que ter a idade mínima de 60 anos e 35 de contribuição. Se mulher, 55 anos de idade e 30 de contribuição. Já com proventos proporcionais a regra era a seguinte: 65 anos de idade se homem, e 60 anos de idade, se mulher, com proventos proporcionais ao tempo de contribuição.

Houve, pela EC $n^{\circ}$ 20/98, a extinção da aposentadoria voluntária exclusivamente por tempo de serviço, passando a valer as regras do regime contributivo de regime de previdência.

Também, por aquele dispositivo, o art. 40 determinava que "o tempo de serviço considerado pela legislação vigente para efeito de aposentadoria, cumprido até que a lei discipline a matéria, será contado como tempo de contribuição".

Apesar de reformado o art. 40, o seu $\S 4^{\circ}$ manteve a revisão dos proventos de aposentadoria, na mesma proporção e na mesma data, sempre que se modificasse a remuneração dos servidores em atividade, sendo também estendido aos inativos quaisquer benefícios ou vantagens posteriormente concedidos aos servidores em atividade, inclusive quando 
decorrentes da transformação ou reclassificação do cargo ou função em que se deve a aposentadoria.

Com o advento da Emenda Constitucional $n^{\circ} 41 / 2003$, rotulada de reforma da previdência, foi implementada a terceira alteração da regra encartada no art. 40, da CF, desde a promulgação do Texto Maior, em 5.10.1988.

Pela atual regra, assim ficou grafada a redação do art. 40, da CF:

Art. 40. Aos servidores titulares de cargos efetivos, da União, dos Estados, do Distrito Federal e dos Municípios, incluídos nas autarquias e fundações, é assegurado regime de previdência de caráter contributivo e solidário, mediante contribuição do respectivo ente público, dos servidores ativos e inativos e dos pensionistas, observados critérios que preservem o equilíbrio financeiro e atuarial e o disposto neste artigo. $\S 1^{\circ}$. Os servidores abrangidos pelo regime de previdência de que trata este artigo serão aposentados, calculados os seus proventos a partir dos valores fixados na forma $\operatorname{dos} \S \S 3^{\circ}$ e 17 : I - por invalidez permanente, sendo os proventos proporcionais ao tempo de contribuição, exceto se decorrente de acidente em serviço, moléstia profissional ou doença grave, contagiosa ou incurável, na forma da lei; II - compulsoriamente, aos 70 anos de idade, com proventos proporcionais ao tempo de contribuição; III - voluntariamente, desde que cumprido tempo mínimo de 10 anos de efetivo exercício no serviço público e cinco anos no cargo efetivo em que se dará a aposentadoria, observadas as seguintes condições: a) 60 anos de idade e 35 de contribuição, se homem, e 55 anos de idade e 30 de contribuição, se mulher; b) 65 anos de idade, se homem, e 60 anos de idade, se mulher, com proventos proporcionais ao tempo de contribuição.

A EC $n^{\circ} 41 / 03$ fixou que os proventos de aposentadoria e as pensões, quando por ocasião de suas concessões seguirão a regra das remunerações utilizadas como base para as contribuições do servidor aos regimes de previdência, com a devida atualização, na forma da lei.

Assim, foi abolida a paridade dos aposentados com os seus pares em atividade, visto que o critério novo é o contributivo, levando em conta os valores recolhidos ao regime previdenciário, com a respectiva atualização. Essa regra é dirigida para as novas aposentadorias a serem concedidas aos servidores que ingressarem no serviço público após a publicação da EC $n^{\circ} 41 / 2003$, pois as antigas, fruto do ato jurídico perfeito e do direito adquirido seguem outra liturgia legal, ou seja, continuam sendo destinatárias de paridade com os servidores em atividade, sendo revistas na mesma proporção e na mesma data que se modificar a respectiva remuneração, dos funcionários ativos, estendido aos inativos quaisquer 
benefícios ou vantagens posteriormente concedidos aos servidores em atividade, na forma do art. $7^{\circ}$ da EC n ${ }^{\circ} 41 / 2003$ :

Art. $7^{\circ}$. Observado o disposto no art. 37, XI, da Constituição Federal, os proventos de aposentadoria dos servidores públicos titulares de cargo efetivo e as pensões dos seus dependentes pagos pela União, Estado, Distrito Federal e Municípios, incluídas suas autarquias e fundações, em fruição da data de publicação desta Emenda, bem como os proventos de aposentadoria dos servidores e as pensões dos dependentes abrangidos pelo art. $3^{\circ}$ desta Emenda, serão revistos na mesma proporção e na mesma data, sempre que se modificar a remuneração dos servidores em atividade, sendo também estendidos aos aposentados e pensionistas quaisquer benefícios ou vantagens posteriormente concedidos aos servidores em atividade, inclusive quando decorrentes da transformação ou reclassificação do cargo ou função em que se deu a aposentadoria ou que serviu de referência para a concessão da pensão, na forma da lei.

O teto salarial e os subtetos estabelecidos para os servidores públicos, previstos no art. 37, XI, da CF e sublinhados pelo citado art. $7^{\circ}$ da EC $n^{0} 41 / 2003$, são aplicáveis à aposentadoria e à pensão, segundo essa nova orientação constitucional. Não resta dúvida que o ponto jurídico é polêmico e será objeto de muita discussão no STF, pois até que ponto uma emenda à Constituição, promovida por constituinte derivado poderá alterar cláusulas pétreas, incorporadas ao patrimônio jurídico dos servidores pela vontade do constituinte originário?

O certo é que pela atual disposição constitucional, promovida pela EC $n^{\circ} 41 / 2003$, os proventos de aposentadoria não poderão exceder o subsídio mensal, em espécie, dos Ministros do Supremo Tribunal Federal, aplicando-lhe como limite, nos Municípios, o subsídio do Prefeito, e nos Estados e no Distrito Federal, o subsídio mensal do Governador no âmbito do Poder Legislativo e o subsídio dos Desembargadores do Tribunal de Justiça, limitando a noventa inteiros e vinte e cinco centésimos por cento do subsídio mensal, em espécie, dos Ministros do Supremo Tribunal Federal, no âmbito do Poder Judiciário, aplicável este limite aos integrantes da carreira do Ministério Público, dos Procuradores e aos Defensores Públicos (art. 37, XII, CF).

Será contado o tempo de contribuição federal, estadual ou municipal para efeito de aposentadoria e o tempo de serviço correspondente para efeito de disponibilidade, não podendo a lei estabelecer qualquer forma de contagem de tempo de contribuição ficta.

A regra previdenciária contida no regime geral de previdência social 
será aplicada subsidiariamente, no que couber, aos servidores públicos titulares de cargo efetivo.

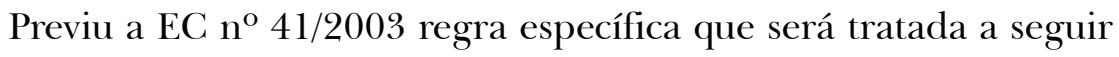
para os servidores públicos que já estivessem no serviço público até a data de sua publicação.

Foram elencados os seguintes requisitos cumulativos para o servidor público se aposentar com proventos integrais, que corresponderão à totalidade da remuneração do servidor no cargo efetivo em que se der a aposentadoria, na forma da lei:

- se homem, 60 anos de idade, e 55 anos de idade, se mulher. Todavia, em se tratando de professor, que tenha o tempo exclusivamente do exercício das suas funções de magistério na educação infantil e no ensino fundamental e médio, a idade será reduzida em cinco anos;

- 35 anos de contribuição, se homem e 30 anos de contribuição se mulher. Utilizada a redução do tempo de contribuição em 5 anos se for professor na situação elencada anteriormente (magistério na educação infantil e ensino fundamental e médio);

- 20 anos de efetivo exercício no serviço público;

- 10 anos de carreira e cinco anos de efetivo exercício no cargo em que se objetiva a aposentadoria. ${ }^{2}$

Por serem regidos pelas normas passadas e mantidos intactos pelo art. $7^{\circ}$ da EC $n^{\circ} 41 / 2003$, os proventos de aposentadoria concedidos pelas regras declinadas no tópico exemplificativo anterior garantem aos proventos de aposentadoria concedidos pelas citadas condições, a revisão na mesma proporção e na mesma data, sempre que se modificar a remuneração dos servidores em atividade.

\section{Regra de transição da aposentadoria voluntária}

$\mathrm{O}$ art. $2^{\circ}$, da $\mathrm{EC} \mathrm{n}^{\mathrm{o}} 41 / 2003$, assegurou o direito à aposentadoria voluntária com proventos calculados de acordo com o art. $40, \S \S 3^{\circ}$ e 17 , da CF, nas seguintes situações:

Art. $2^{\circ}$. Observado o disposto no art. $4^{\circ}$ da Emenda Constitucional $n^{\circ} 20$, de 15 de dezembro de 1998, é assegurado o direito de opção pela aposentadoria voluntária com proventos calculados de acordo com o art. $40, \S \S 3^{\circ}$ e 17 , da Constituição Federal, àquele que tenha ingressado regularmente em cargo

${ }^{2}$ Cf. MORAES, Alexandre de. Constituição do Brasil Interpretada. 4. ed., 2004, p. 995.

A \& C R. de Dir. Administrativo e Constitucional, Belo Horizonte, ano 5, n. 19, p. 161-199, jan./mar. 2005 
efetivo na Administração Pública direta, autárquica e fundacional, até a data de publicação daquela Emenda, quando o servidor, cumulativamente: I - tiver 53 anos de idade, se homem, e 48 anos de idade, se mulher; II - tiver cinco anos de efetivo exercício no cargo em que se der a aposentadoria; III - contar tempo de contribuição igual, no mínimo, à soma de: a) 35 anos, se homem, e 30 anos, se mulher; e b) um período adicional de contribuição equivalente a vinte por cento do tempo que, na data de publicação daquela Emenda, faltaria para atingir o limite de tempo constante da alínea a deste inciso. $\S 1^{\circ} \mathrm{O}$ servidor de que trata este artigo que cumprir as exigências para aposentadoria na forma do caput terá os seus proventos de inatividade reduzidos para cada ano antecipado em relação aos limites de idade estabelecidos pelo art. $40, \S 1^{\circ}$, III, $a$, e $\S 5^{\circ}$ da Constituição Federal, na seguinte proporção: I - três inteiros e cinco décimos por cento, para aquele que completar as exigências para aposentadoria na forma do caput até 31 de dezembro de 2005; II - cinco por cento, para aquele que completar as exigências para aposentadoria na forma do caput a partir de $1^{\circ}$ de janeiro de 2006. $\S 2^{\circ}$ Aplica-se ao magistrado e ao membro do Ministério Público e de Tribunal de Contas o disposto neste artigo. $\$ 3^{\circ} \mathrm{Na}$ aplicação do disposto no $\S 2^{\circ}$ deste artigo, o magistrado ou o membro do Ministério Público ou de Tribunal de Contas, se homem, terá o tempo de serviço exercido até a data de publicação da Emenda Constitucional no 20, de 15 de dezembro de 1998, contado com acréscimo de dezessete por cento, observado o disposto no $\S 1^{\circ}$ deste artigo. $\S 4^{\circ} \mathrm{O}$ professor, servidor da União, dos Estados, do Distrito Federal e dos Municípios, incluídas suas autarquias e fundações, que, até a data de publicação da Emenda Constitucional no 20, de 15 de dezembro de 1998, tenha ingressado, regularmente, em cargo efetivo de magistério e que opte por aposentar-se na forma do disposto no caput, terá o tempo de serviço exercido até a publicação daquela Emenda contado com o acréscimo de dezessete por cento, se homem, e de vinte por cento, se mulher, desde que se aposente, exclusivamente, com tempo de efetivo exercício nas funções de magistério, observado o disposto no $\S 1^{\circ} . \S 5^{\circ} \mathrm{O}$ servidor de que trata este artigo, que tenha completado as exigências para aposentadoria voluntária estabelecidas no caput, e que opte por permanecer em atividade, fará jus a um abono de permanência equivalente ao valor da sua contribuição previdenciária até completar as exigências para aposentadoria compulsória contidas no art. 40, § $1^{\circ}$, II, da Constituição Federal.

Assim, para ter direito à aposentadoria voluntária com proventos calculados com base no art. $40, \S \S 3^{\circ}$ e 17 , da CF, o servidor terá que preencher cumulativamente os seguintes requisitos:

- 53 anos de idade, se homem e, 48 anos de idade, se mulher;

- cinco anos de efetivo exercício no cargo em que se dará a inativação;

- tempo de contribuição igual, no mínimo, à soma de: a) 35 anos, se homem e 30 anos, se mulher; e

- tempo de contribuição igual, no mínimo, à soma de: a) 35 anos, se homem e 30 anos, se mulher; e $b$ ) um período adicional equivalente 
a 20\% do tempo que, na data da publicação da EC n ${ }^{\circ}$ 20/2003, faltaria para atingir o limite de tempo constante da alínea anterior.

Foi estipulada, portanto, a idade mínima de 53 anos para homem e 48 anos para a mulher, para se aposentar.

A atual regra de transição permite que haja alteração do quantum recebido nos proventos de aposentadoria do servidor público. Isto porque, o art. $2^{\circ}$, da EC $n^{\circ} 41 / 2003$, estipula que o servidor que se aposentar, pelas regras passadas, terá o seu provento reduzido para cada ano antecipado em relação aos limites de idade estabelecidos na regra geral, ou seja, 60 anos para homem e 55 anos para as mulheres.

Na prática, é permitida, pela regra de transição, a aposentadoria para os servidores que tenham ingressado regularmente em cargo efetivo na Administração Pública, até 19 de dezembro de 2003, data da publicação da EC $n^{\circ} 41 / 2003$, a regra anterior, todavia, com o pagamento de um pedágio, descontado do sofrido provento.

Essa redução é inconstitucional, pois a EC no 41/2003 não pode alterar a situação jurídica de quem já era servidor público, criando redução nominal dos proventos, para cada ano antecipado em relação aos limites de idade estabelecidos pela nova regra geral. Mesmo tentando manter eficaz a regra do direito adquirido, a citada Emenda Constitucional dribla a conquista do servidor quando desconta os anos não atingidos pela nova orientação geral.

Essa manobra fere o direito adquirido dos servidores públicos que pretendem valer-se das regras pré-estabelecidas quando dos seus ingressos no seio do serviço público. A partir do momento que o subsídio e os vencimentos dos ocupantes de cargos e empregos públicos são irredutíveis (art. 37, XV, da $\mathrm{CF}$ ), os proventos de aposentadoria seguem a mesma liturgia, sendo vedada a redução, salvo se por decisão judicial.

Apesar de ter decidido que não há direito adquirido a regime jurídico, o Judiciário veda a redução de vencimentos, que importe em diminuição nominal do que era recebido pelo servidor: ${ }^{3}$

Policiais militares. Alteração de gratificação com redução no seu percentual. - É firme a jurisprudência desta Corte no sentido de que não há direito adquirido a regime jurídico e de que não há ofensa ao princípio constitucional da irredutibilidade quando o montante dos vencimentos não é diminuído com a alteração das gratificações que os integram. Dessas orientações (que decorrem, a título

${ }^{3}$ STF, Rel. Min. Moreira Alves, RE 244610-/PR, $1{ }^{a}$ T., DJ de 29.6.2001, Ementário n 2037-5.

A \& C R. de Dir. Administrativo e Constitucional, Belo Horizonte, ano 5, n. 19, p. 161-199, jan./mar. 2005 
exemplificativo, dos RREE $n^{\circ}$ s 267.797, 183.700, 205.481, 250.321, 244.611, 236.239, 242.803 e 247.899) não divergiu o acórdão recorrido. - Por outro lado, a questão relativa ao art. 37, X, da Carta Magna não foi prequestionada (Súmulas $n^{\circ}$ s 282 e 356), e, no tocante à pretendida ofensa ao princípio da isonomia inserto no art. $39, \S 1^{\circ}$, da Constituição, é ela manifestamente improcedente no caso, porquanto esse dispositivo constitucional, ao contrário do que pretendem os recorrentes, não cogita da impossibilidade da redução de vantagens, desde que não haja a redução do valor nominal dos vencimentos. Recurso extraordinário conhecido pela letra "c" do inciso III do art. 102 da Constituição, mas não provido.

Entendo que essa redução, que não estava prevista na regra de transição da EC n ${ }^{\circ}$ 20/98, é inconstitucional, por afronta ao art. 60, §4 , IV, da CF.

Em abono ao que foi dito, é da lavra de Ives Gandra ${ }^{4}$ o seguinte comentário:

...o constituinte, ao pretender imutáveis determinadas cláusulas, normas, princípios ou ideologias, impõe sua inalterabilidade, não permitindo que os poderes constituídos, que poderão se tornar poderes constituintes derivados, venham, quanto àquelas cláusulas, a exercer seu poder ligiferante.

A redução prevista no $\S 1^{\circ}$, do art. $2^{\circ}$, da $\mathrm{EC} \mathrm{n}^{\circ} 41 / 2003$, é a seguinte: - o servidor que completar as exigências para aposentadoria na regra de transição até 31 de dezembro de 2005, terá uma redução de três inteiros e cinco décimos por cento;

- já os demais, que completarem as exigências para aposentadoria na regra de transição a partir da $1^{\circ}$ de janeiro de 2006, sofrerão o desconto de $5 \%$.

Fica cara a conta de quem resolver utilizar-se da regra de transição, tendo em vista que o servidor que se aposentar com 54 anos de idade, até 31.12.2005, terá uma diminuição de seus futuros proventos na ordem de $21 \%$, utilizando-se o decréscimo de 3,5\%, para cada ano (seis) em que antecipou a idade prevista pela regra geral (60 anos).

Pior fica para a outra situação, onde o aposentado após 1.1.2006 sofrerá um decréscimo de $36 \%$ de seus proventos de aposentadoria, pois ocorrerá redução de $5 \%$ para cada um dos seis anos antecipados.

Essa regra de transição foi concebida para inibir o servidor de valerse dos seus direitos adquiridos, pois reduz o que era permitido, criando uma regra geral exatamente para impedir ou inibir a aposentação, sob pena de 4 MARTINS, Ives Gandra da Silva. Constituição Federal - 15 anos - Mutação e Evolução. Ed. Método, 2003, p. $182-183$.

A \& C R. de Dir. Administrativo e Constitucional, Belo Horizonte, ano 5, n. 19, p. 161-199, jan./mar. 2005 
reduzirem-se os proventos. Tanto é assim, que o servidor que preencher os requisitos para aposentadoria pela regra de transição e permanecer em atividade fará jus a um abono rotulado de permanência, equivalente ao valor da sua contribuição previdenciária até completar as exigências para a aposentadoria compulsória.

A EC $n^{\circ} 41 / 2003$, na hipótese de aposentadoria voluntária antecipada, criou a fórmula do reajustamento dos benefícios em valores reais, para manter, em caráter permanente, o valor dos mesmos, sem decréscimos. Por valor real entendo que deverá ser reposta a defasagem do custo de vida ou a inflacionária, pois do contrário não seria real e sim nominado a regra de reajustamento dos benefícios em valores reais, para manter, em caráter permanente, o valor dos mesmos, sem decréscimos. Por valor real entendo que deverá ser reposta a defasagem do custo de vida ou a inflacionária, pois do contrário não seria real e sim nominal a regra de reajustamento.

Sobre valor real é de se abrir parênteses para registrar que vem estabelecido no art. $7^{\circ}$, inc. IV da CF, que se endereça ao servidor público em submissão ao art. $39, \S 2^{\circ}$ da CF.

Ao discorrer sobre a revisão estipendial feita em valores reais, com base no que vem disposto no art. $7^{\circ}$, IV, da CF, aplicado ao servidor público por determinação do art. 39, §2º , do mesmo Texto Maior, Sérgio D’Andréa ${ }^{5}$ aduz:

A revisão é mecanismo de preservação do padrão remuneratório, no seu valor real, pois que a irredutibilidade não é, apenas, nominal, mas também real, o que se conclui, com facilidade, em decorrência do disposto nos mencionados artigos combinados com o do art. $7^{\circ}$, IV, que, ao dar os critérios norteadores do salário mínimo, impõe que os "reajustes periódicos" respectivos "lhe preservem o poder aquisitivo". Destarte, o índice revisional tem de, para compensar a defasagem inflacionária, ser o que traduz a perda do poder aquisitivo da moeda (índice de preços ao consumidor, disponibilidade interna, divulgado pela Fundação Getulio Vargas).

\section{E Adilson Abreu Dallari ${ }^{6}$ não discrepa o que foi dito:}

Por "revisão geral" deve ser entendido apenas o reajuste da perda do valor aquisitivo da moeda, que atinge a todos os servidores indistintamente.

A irredutibilidade da aposentadoria é a fórmula que garante não apenas o valor nominal do provento, mas o seu valor em face da vida econômica (valor real).

${ }^{5}$ D'ANDRÉA, Sérgio. Regime Constitucional dos Servidores Públicos. 2. ed. Revista dos Tribunais, p. 58.

${ }^{6}$ DALLARI, Adilson de Abreu. Comentários à Constituição. Freitas Bastos, 1991, p. 167. v. 3. 
A respeito do que foi dito, seguem as firmes palavras do Min. Marco Aurélio: ${ }^{7}$

Não consigo, Senhor Presidente, conciliar esse princípio da irredutibilidade com a noção de que ele se refere apenas ao valor nominal e não ao conteúdo representado pela própria remuneração, em face da vida econômica.

E, para arrematar, nada mais preciso do que trazer a lume as sempre autorizadas palavras do ínclito Ministro Moreira Alves: ${ }^{8}$

Essa, Sr. Presidente, é a tese que sempre tenho sustentado: o reajuste para os fins da Constituição é sempre o mesmo para o efeito de recomposição do valor econômico da moeda.

$\mathrm{O} \S 2^{\circ}$ do art. $2^{\circ}$, da EC $n^{\circ} 41 / 2003$, estendeu a regra de transição a Magistrados, Membros do Ministério Público e Tribunal de Contas.

Por sua vez, o $\S 3^{\circ}$ do art. $2^{\circ}$, da EC $n^{\circ} 41 / 2003$, acresce ao Magistrado, membro do Ministério Público e do Tribunal de Contas, se homem, $17 \%$ por do tempo de serviço exercido até a publicação da EC $\mathbf{n}^{\circ}$ 20/98.

Alexandre de Moraes justifica esta regra, da seguinte forma: ${ }^{9}$

A razão dessa previsão constitucional está no fato de que, até a publicação da EC $n^{\circ}$ 20/98, independentemente do sexo, todos os magistrados, membros do Ministério Público e de Tribunais de Contas, aposentavam-se pelas mesmas regras especiais que exigiam 30 anos de serviços para aposentadoria. Com as alterações constitucionais, a aposentadoria dos magistrados, membros do Ministério Público e dos Tribunais de Contas, passou a ser regida pelas regras gerais do art. 40 da Constituição Federal e pelas regras de transição, primeiro do art. $8^{\circ}$ da EC ${ }^{\circ}$ 20/98 e, posteriormente, do art. $2^{\circ}$, $\S 3^{\circ}$, da EC $n^{\circ} 41 / 03$, que diferenciam o servidor em razão do sexo. Dessa forma, a previsão de um acréscimo de $17 \%$ em relação ao tempo de serviço exercido até a publicação da EC no 20/98 em relação aos magistrados, membros do Ministério Público e de Tribunais de Contas do sexo masculino, pretende, durante o período de transição manter a igualdade, de maneira a equilibrar a situações, independentemente do sexo.

O professor, da União, dos Estados, do Distrito Federal e dos Municípios abrangidas as Fundações e Autarquias, que até a data de publicação da EC $\mathrm{n}^{\circ} 20$, de 15 de dezembro de 1998, tenha ingressado no serviço

\footnotetext{
${ }^{7}$ Voto proferido na ADIn n 646-1-RS, DJU de 18.6.1993.

${ }^{8}$ Voto proferido na ADIn n $646-1-R S$, DJU de 18.6.1993.

${ }^{9}$ Alexandre de Moraes, cit. ant., p. 959.
}

A \& C R. de Dir. Administrativo e Constitucional, Belo Horizonte, ano 5, n. 19, p. 161-199, jan./mar. 2005 
público, poderá optar por aposentar-se na forma do caput do art. $2^{\circ}$ da EC $n^{\circ} 41 / 2003$, terá o tempo acrescido também de $17 \%$, se homem, e de $20 \%$ se mulher, desde que se aposente, exclusivamente, com tempo de efetivo exercício nas funções de magistério, observada a regra redutória (pedágio) do $\S 1^{\circ}$ do mesmo art. $2^{\circ}$ da última Emenda Constitucional (no 41/2003).

Regra de transição para qualquer servidor que completar os requisitos do art. $2^{\circ}$ da $\mathrm{EC}^{\mathrm{o}}$ 41/2003 até 31.12.2005:

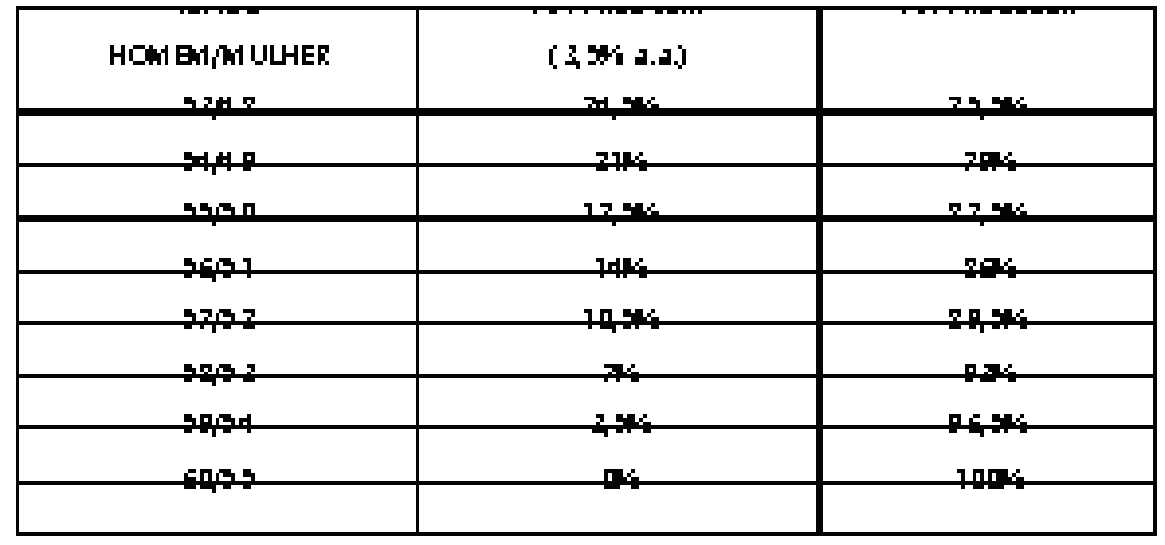

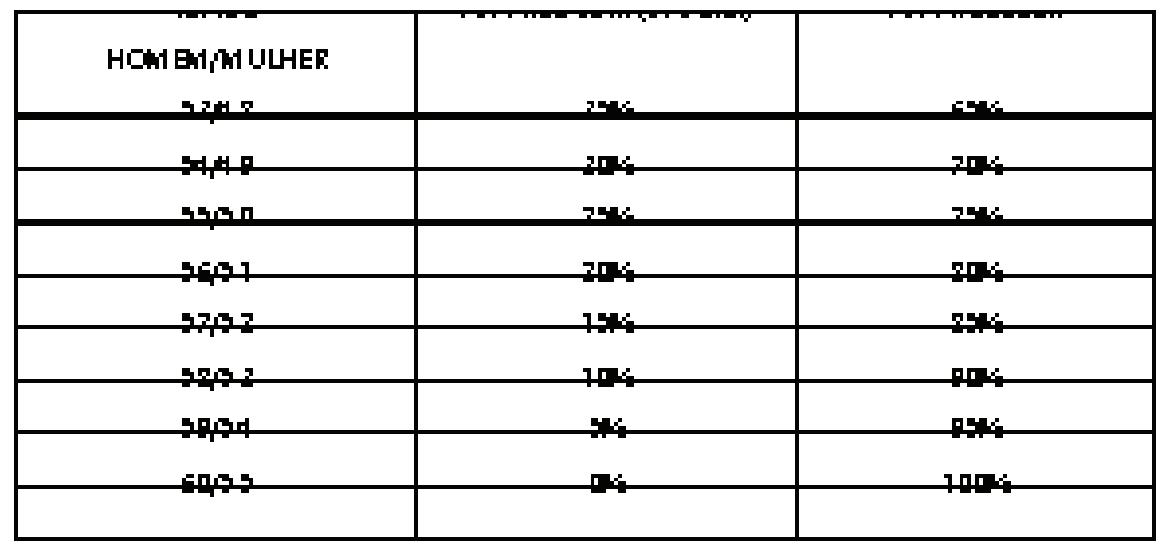

A \& C R. de Dir. Administrativo e Constitucional, Belo Horizonte, ano 5, n. 19, p. 161-199, jan./mar. 2005 


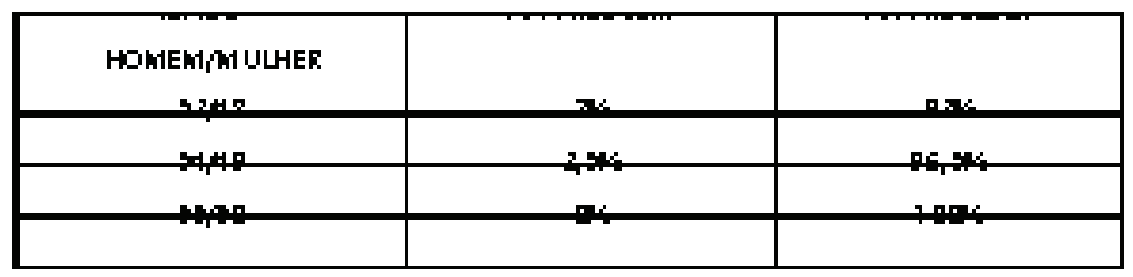

aplicada a redução de idade e temṕo de contribuição prevista no $\$ 5^{\circ}$ do art. 40

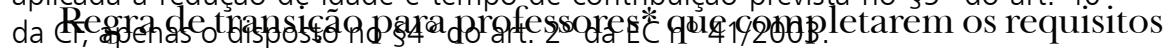
do art. $2^{\circ}$ da EC $\mathrm{n}^{\mathrm{O}} 41 / 2003$ a partir de 1.1.2006:

** Para cálculo do redutor previsto no $\S 1^{\circ}$ do art. $2^{\circ}$ da $E C n^{\circ} 41 / 2003$ aplica-se a redução estabelecida no $\S 5^{\circ}$ do art. 40 da CF.

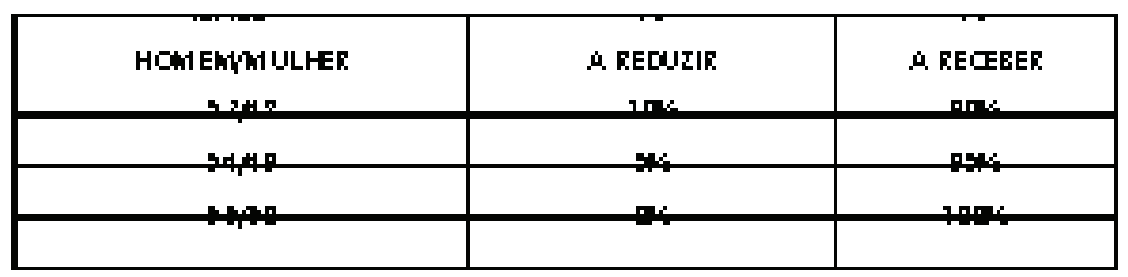

III Cáf́liçada reducão de idade e tempo de contribuicão prevista no $50^{\circ}$ do art. 40

O $\S 2^{\circ}$, do art. 40 da CF, com redação dada pela EC no 20/98 foi

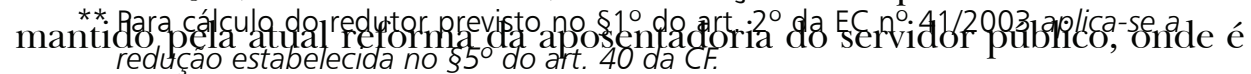
determinado que os proventos de aposentadoria e as pensões, por ocasião de sua concessão, não poderão exceder à remuneração do respectivo servidor, no cargo em que se deu a aposentadoria ou que serviu de referência para a concessão da pensão.

Essa regra deve ser interpretada sistematicamente com o que vem estabelecido no art. $7^{\circ}$ da $\mathrm{EC} \mathrm{n}^{\circ} 41 / 2003$, tendo em vista que os servidores públicos já aposentados, ou suas pensionistas, continuam sendo destinatários de paridade com os servidores em atividade, recebendo qualquer benefícios que forem endereçados a eles. Ou seja, poderão na inatividade ganhar mais do que em atividade, pois a regra de reajuste de seus proventos não está engessada. É óbvio que tal regramento constitucional, previsto na EC n ${ }^{\circ} 41 / 2003$, visou preservar o direito adquirido e o ato jurídico 
perfeito das respectivas aposentadorias, pois a regra do $\S 2^{\circ}$ do art. 40 da CF é destinada para as situações jurídicas novas, ou seja, para aqueles que ingressarem no serviço público após a EC atual (nº 41/2003).

Este esclarecimento é importante, pois se não for observada à risca esta situação, muitas lesões serão verificadas, com prejuízos inconstitucionais a aposentados e pensionistas.

Pois bem, deixando de lado esta questão, é de se sublinhar que na fixação dos proventos dos aposentados, as regras de reajustes e atualização sofreram sérias alterações pela EC no 41/2003, que estabeleceu hipóteses vinculadas às situações jurídicas distintas.

Nesse enredo, pode-se destacar as situações, da seguinte forma:

- servidores (aposentados ou em atividade) que cumpriram os requisitos para se aposentar até a data da publicação da EC n ${ }^{\circ} 41 /$ 2003. Essa situação é aquela já declinada pelo art. $7^{\circ}$ da respectiva Emenda Constitucional $\mathrm{n}^{\mathrm{o}} 41$, onde o servidor possui intacta a regra de paridade estipendial entre o seu provento e os vencimentos dos seus pares em atividade no cargo em que se der a aposentadoria, com a revisão na mesma data e proporção, sempre que se modifique a remuneração do servidor em atividade, sendo estendidos quaisquer vantagens posteriores, sem que ocorra violação ao $\S 2^{\circ}$, do art. 40 da CF;

- servidores públicos que estão em atividade na data da publicação da EC $n^{\circ} 41 / 2003$ e completaram os requisitos para se aposentarem anteriormente. É a hipótese de quem completou 20 anos de efetivo serviço público, 10 anos de carreira e 5 de efetivo exercício no cargo em que se der a aposentadoria, possui o direito manter a integralidade da paridade com o seu cargo em atividade, nas condições declinadas na situação anterior;

- servidores públicos em atividade na data da publicação da EC n ${ }^{\circ}$ 41/2003 que não atingiram os requisitos novos. Para os servidores em atividade quando da alteração da regra de aposentadoria, é mantida a integralidade dos proventos, que corresponderão à totalidade da remuneração do servidor quando em atividade no cargo efetivo em que se deu a aposentadoria, não lhe sendo assegurada a regra de paridade com os servidores ativos, o que significa dizer que os seus proventos não receberão o mesmo reajuste e nem será na mesma data que forem alterados os ven- 
cimentos dos servidores ativos. E para piorar a situação dos servidores que ingressaram no serviço público na esperança de ter uma velhice amparada pela construção de um passado funcional, não será estendido para o inativo, na presente situação, nenhuma progressão funcional ou vantagem paga posteriormente à data da sua aposentação para o seu ex-paradigma ativo. O constituinte derivado preservou apenas a manutenção do valor real do benefício, com reajustes que permitam esse tratamento estipendial. Por manutenção do valor real entendo que a deterioração da moeda, tal como a inflação oficial, terá que ser calculada para mediar a perda da aposentadoria, com a finalidade de incorporar nos futuros reajustes dos proventos do servidor público essa defasagem, ocasionada pela elevação do custo de vida. Na prática, somente o manto protetor do Poder Judiciário é que terá que resgatar a dignidade dos futuros aposentados, mantendo-lhes a integralidade do benefício, caso essa regra não seja cumprida.

- servidores públicos que ingressem na Administração Pública em data posterior à da EC no 41/2003. Essa situação jurídica é bem nova, não sendo mantida a manutenção de integridade dos proventos e nem a paridade com o cargo ativo em que se deu a aposentadoria. Os valores dos proventos de aposentadoria desses servidores serão calculados por ocasião da aludida concessão do benefício, levando-se em conta as remunerações utilizadas como base para as contribuições do servidor aos regimes de previdência, devidamente atualizados e respeitado o limite vigente para o valor dos benefícios do regime geral de previdência social (art. 201, CF) que atualmente está na órbita de $\mathrm{R} \$ 2.508,72$ (valor de agosto/2004) para manter intacto este valor, ele será atualizado, para preservar, em caráter permanente, seu valor real. Os proventos sofrerão uma suplementação, para que o servidor público possa viver condignamente e não se tornar mais um indigente. Nessa suplementação serão feitos cálculos atuariais, levando-se em conta o valor contribuído pelo servidor público, no curso dos anos. Assim ficou redigido o $\S 3^{\circ}$, do art. 40 da $\mathrm{CF}$, com a redação que lhe deu a EC n41: “ $3^{\circ}$ - Para o cálculo dos proventos de aposentadoria, por ocasião da sua concessão, serão consideradas as remunerações utilizadas como base para as contribuições do servidor aos regimes de previdência de que tratam este artigo e o art. 201, na 
forma da lei”.

Para as pensionistas o cálculo dos seus benefícios segue o que vem estipulado no art. 40, $\S 7^{\circ}$ da CF, também fruto da nova EC n ${ }^{\circ} 41 / 2003$ : " $7^{\circ}$. Lei disporá sobre concessão do benefício de pensão por morte, que será igual: I - ao valor da totalidade dos proventos do servidor falecido, até o limite máximo estabelecido para os benefícios do regime geral de previdência social de que trata o art. 201, acrescido de setenta por cento da parcela excedente a este limite, caso aposentado à data do óbito; ou II - ao valor da totalidade em que se deu o falecimento, até o limite máximo estabelecido para os benefícios do regime geral de previdência social de que trata o art. 201, acrescido de setenta por cento da parcela excedente a este limite, caso em atividade na data do óbito".

Como visto, a EC n ${ }^{\circ}$ 41/2003 alterou a regra da pensão por morte do servidor, que no sistema anterior garantia à pensionista integralidade do valor recebido em virtude do cargo exercido pelo servidor público. Pela nova e atual sistemática, a EC n ${ }^{\circ}$ 41/2003 estabeleceu teto para a concessão da integralidade do benefício de pensão por morte, que é o utilizado para limitar os benefícios do regime geral de previdência social, no importe de $\mathrm{R} \$ 2.508,72$ (agosto/2004). O teto, a partir de dezembro de 2003 é reajustado, com a finalidade de garantir o valor real da pensão, em caráter permanente, atualizado pelos mesmos índices aplicados aos benefícios do regime geral de previdência social (art. $5^{\circ}$, da EC n ${ }^{\circ} 41 / 03$ ).

Volto, por outro lado, a insistir na tecla do aumento real, que para preservar permanentemente o valor da pensão deverá receber o reajuste do custo de vida, medido pela inflação oficial, pois senão este valor real será corroído mês a mês. Este sistema, se não for cumprido à risca, trará muitas defasagens para as pensionistas, haja vista o que acontece com as aposentadorias recebidas pelos beneficiários da Previdência Oficial. Tapar o sol com a peneira é perigoso, pois inúmeras viúvas e dependentes irão sobreviver com o valor do teto, que não poderá ser deteriorado pela falta da preservação do valor real dos proventos.

O limite máximo de $\mathbf{R} \$ 2.508,72$ sofrerá um acréscimo estabelecido para os benefícios do regime geral de previdência social da seguinte parcela:

- 70\% da diferença entre o valor recebido pelo servidor na data do óbito e o limite máximo fixado;

- 70\% da diferença entre a remuneração recebida pelo servidor público por ocasião de seu vínculo ativo e o limite estipulado como máximo.

A \& C R. de Dir. Administrativo e Constitucional, Belo Horizonte, ano 5, n. 19, p. 161-199, jan./mar. 2005 
Dessa forma, a pensão do passado foi totalmente desnaturada, tendo em vista que o benefício da pensão por morte passou a ser composta por uma parcela fixa $(\mathrm{R} \$ 2.508,72)$ e uma complementar $(70 \%$ da diferença já declinada no item anterior).

Alexandre de Moraes $^{10}$ traz exemplo concreto sobre o que foi dito, tomando como base o valor do teto previdenciário de dezembro/2003 $(\mathrm{R} \$ 2.400,00)$ :

Exemplificativamente, se a totalidade dos proventos do servidor aposentado correspondia a $\mathrm{R} \$ 4.400,00$ à data do óbito, o benefício da pensão por morte será calculado da seguinte forma: - parcela fixa: limite máximo de $\mathbf{R} \$ 2.400,00$ (devidamente corrigidos); - parcela complementar: $70 \%$ da diferença entre o valor da totalidade dos proventos do servidor falecido ( $\mathrm{R} \$ 4.400,00)$ e o limite máximo $(\mathrm{R} \$ 2.400,00)$, ou seja, $70 \%$ de $\mathbf{R} \$ 2.000,00=\mathrm{R} \$ 1.400,00$; - benefício da pensão $=$ $\mathrm{R} \$ 2.400,00$ (parcela fixa) + $\mathrm{R} \$ 1.400,00$ (parcela complementar) $=\mathrm{R} \$ 3.800,00$.

O $\S 8^{\circ}$ do art. 40 da CF, também concebido pela EC n ${ }^{\circ} 41 / 2003$, assegura o reajuste dos benefícios, tanto de aposentadoria como de pensão, para preservar-lhes, em caráter permanente, o valor real, conforme critérios estabelecidos em lei.

Importante deixar nítido que a regra da EC no 41/2003 só é aplicada aos novos casos, ou seja, não possui o condão de retroagir para alcançar as pensões ou aposentadorias anteriores à sua existência.

Basta o servidor ou a pensionista reunirem requisitos necessários para a obtenção desses benefícios, com base nos critérios anteriores, elencados pela legislação revogada, que ele não perde o direito que já estava adquirido.

Não perde o servidor os direitos adquiridos pelo fato de não ter requerido a concessão do benefício: ${ }^{11}$

Se, na vigência da lei anterior, o funcionário havia preenchido todos os requisitos para a aposentadoria, não perde os direitos adquiridos pelo fato de não haver solicitado a concessão.

Em outro histórico julgado, o Eg. Sodalício manteve intacto esse posicionamento: ${ }^{12}$

Se, na vigência da lei anterior, o servidor preenchera todos os requisitos exigidos, o fato de, na sua vigência, não haver requerido a aposentadoria, não o fez perder o seu direito já que estava adquirido.

\footnotetext{
${ }_{10}$ MORAES, Alexandre de, cit. ant., p. 965.

${ }^{11}$ STF, Rel. Min. Luis Gallotti, MS n 11.395, Plano, RDA 82:186.
}

A \& C R. de Dir. Administrativo e Constitucional, Belo Horizonte, ano 5, n. 19, p. 161-199, jan./mar. 2005 
O Min. Carlos Velloso, em sede doutrinária, deixou assente: ${ }^{13}$

É que as condições da aposentação - proventos e vantagens financeiras — são direitos que o servidor adquire com base na legislação vigente no momento em que tinha condições legais para requerer e exercitar o seu direito.

\section{Do art. 186, da Lei n 8.112/90 e a Emenda Constitucional} $n^{\circ} 41 / 2003$

Como visto anteriormente, o art. 186 da Lei $\mathrm{n}^{\circ}$ 8.112/90 deverá ser adequado ao teor da EC $n^{\circ} 41 / 2003$, que alterou a aposentadoria por tempo de serviço (voluntária) nos moldes declinados nos tópicos I, II e III, constantes no presente artigo.

Para melhor visualização da reforma da Constituição Federal e a previdência dos servidores públicos, aí incluídas aposentadorias e pensões, basta se ater ao quadro exemplificativo feito por Alexandre de Moraes, ${ }^{14}$ assim construído:

V Da Lei $n^{\circ} 10.887$, de 18 de junho de 2004

A Lei $n^{\circ} 10.887 / 2004$ dispõe sobre a aplicação de disposições da Emenda Constitucional $\mathrm{n}^{\mathrm{o}} 41$, de 19 de dezembro de 2003, alterando dispositivos das Leis $\mathrm{n}^{\text {os }} 9.717 / 98,9.782 / 99,8.213 / 91$ e 9.532/97, dando outras providências.

$\mathrm{O} \S 3^{\circ}$, do art. 40 da CF estipula que os proventos de aposentadoria,

\footnotetext{
12 STF, Rel. Min. Evandro Lins, RE n 62.361/SP, Pleno, RTJ 48/392.

${ }^{13}$ VELLOSO, Carlos Mário da Silva. Temas de Direito Público. Del Rey, 1993, p. 440.

${ }^{14}$ MORAES, Alexandre de. Direito Constitucional. 15. ed. Atlas, 2004, p. 368.
} 


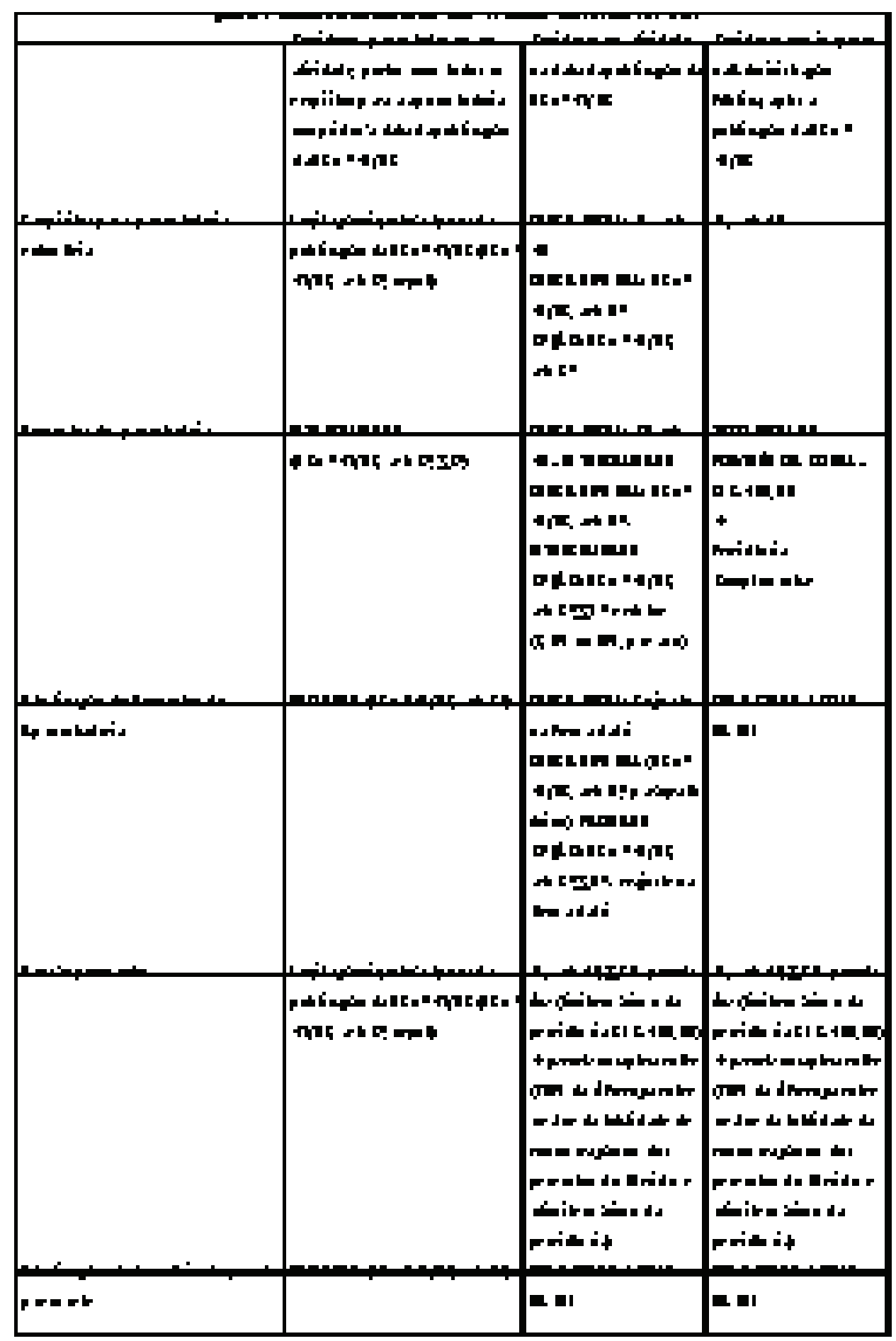

A \& C R. de Dir. Administrativo e Constitucional, Belo Horizonte, ano 5, n. 19, p. 161-199, jan./mar. 2005 
quando por ocasião da sua concessão, serão calculados com base na remuneração do servidor no cargo efeito em que se der a aposentadoria e, na forma da lei, corresponderão à totalidade da remuneração. Assim, coube ao art. $1^{\circ}$ da Lei $\mathrm{n}^{\circ} 10.887 / 2004$ estipular que será considerada a média aritmética simples das maiores remunerações, utilizadas como base para as contribuições do servidor aos regimes de previdência a que esteve vinculado, correspondentes a oitenta por cento de todo o período contributivo desde a competência julho de 1994 ou desde a do início da contribuição, se posterior àquela competência, litteris:

Art. $1^{\circ}$. No cálculo dos proventos de aposentadoria dos servidores titulares de cargo efetivo de qualquer dos poderes da União, dos Estados, do Distrito Federal e dos Municípios, incluídas suas autarquias e fundações, previsto no $§ 3^{\circ}$, do art. 40 da Constituição Federal e no art. $2^{\circ}$ da EC n ${ }^{\circ} 41$, de 19 de dezembro de 2003, será considerada a média aritmética simples das maiores remunerações, utilizadas como base para as contribuições do servidor aos regimes de previdência a que esteve vinculado, correspondentes a oitenta por cento de todo o período contributivo desde a competência julho 1994 ou desde o início da contribuição, se posterior àquela competência. $\S 1^{\circ}$ As remunerações consideradas no cálculo do valor inicial dos proventos terão os seus valores atualizados, mês a mês, de acordo com a variação integral do índice fixado para a atualização dos salários de contribuição considerados no cálculo dos benefícios do regime geral da previdência social. §2 A base de cálculo dos proventos será a remuneração do servidor no cargo efetivo nas competências a partir de julho de 1994 em que não tenha havido contribuição para regime próprio. $\S 3^{\circ}$ Os valores das remunerações a serem utilizados no cálculo de que trata este artigo serão comprovados mediante documento fornecido pelos órgãos e entidades gestoras dos regimes de previdência aos quais o servidor esteve vinculado. $\S 4^{\circ}$ Para os fins deste artigo, as remunerações consideradas no cálculo da aposentadoria atualizadas na forma do $\S 1^{\circ}$ deste artigo, não poderão ser: I - inferiores ao valor do salário mínimo; II - superiores ao limite máximo do salário de contribuição, quanto aos meses em que o servidor esteve vinculado ao regime geral da previdência social. $\S 5^{\circ}$ Os proventos, calculados de acordo com o caput deste artigo, por ocasião de sua concessão, não poderão ser inferiores ao valor do salário-mínimo nem exceder à remuneração do respectivo servidor no cargo efetivo em que se deu a aposentadoria.

Como visto, será considerada a média aritmética simples das maiores remunerações, utilizadas como base para as contribuições do servidor aos regimes de previdência a que o servidor esteve vinculado, correspondentes a $80 \%$ de todo o período contributivo, atualizadas mês a mês, de acordo com a variação integral do índice utilizado pelo regime geral da previdência social, no cálculo dos seus benefícios. Na prática, equiparar a fórmula de concessão da aposentadoria voluntária do servidor público com os parâmetros utilizados pela Previdência Social para o pagamento dos seus 
sofridos aposentados é criar uma geração "nova" de aposentados, que se não tiverem uma previdência complementar, capaz de agregar ao provento básico uma suplementação de renda, impossibilitará que o ser humano se inative, pois a sua velhice lhe trará certas dificuldades financeiras.

A Emenda Constitucional no 20/98 autorizou a criação de regimes de previdência complementar para servidores efetivos da União, Estados, Distrito Federal e Municípios, na forma do art. 202 da CF, que será obrigatório para os servidores titulares de cargo efetivo que ingressarem no serviço público após a instituição do respectivo plano complementar.

Pois bem, voltando ao núcleo central, a lei em tela, na hipótese de não-instituição de contribuição para o regime próprio durante o período referido no caput do art. $1^{\circ}$, será considerada como base de cálculo dos proventos, a remuneração do servidor no cargo efetivo no mesmo período.

Para fins de cálculo dos proventos as remunerações da nova aposentadoria não poderão ser:

- inferiores ao valor do salário mínimo;

- superiores aos valores dos limites máximos de remuneração no serviço público;

- superiores ao limite máximo do salário de contribuição, quanto à vinculação.

Mesmo não podendo exceder a remuneração recebida, fruto do cargo ativo, os proventos devem manter a proporcionalidade do valor real do valor concedido à título de proventos.

Os proventos da pensionista, segundo o art. $2^{\circ}$ da Lei ${ }^{\circ} 10.887 / 2004$, será igual:

- à totalidade dos proventos percebidos pelo aposentado na data anterior à do óbito, até o limite máximo estabelecido para benefícios do regime geral da previdência social ( $\mathrm{R} \$ 2.508,72$ - agosto/2004), acrescido de $70 \%$ da parcela excedente a este limite;

- à totalidade da remuneração de contribuição percebida pelo servidor no cargo efetivo na data anterior a do óbito, até o limite da previdência social $(\mathrm{R} \$ 2.508,72)$ acrescido de $70 \%$ da parcela excedente a este limite;

Esse artigo supra declinado se compatibiliza com o que vem estipulado no art. $40, \S 7^{\circ}$, da $\mathrm{CF}$.

Para fins do que vem encartado no inciso XI do art. 37 da CF, a União, os Estados, o Distrito Federal e os Municípios manterão regime próprio 
de previdência social de que trata o art. 40 da Lex Legum, integrando os dados relativos às remunerações, proventos e pensões pagos aos respectivos servidores e militares, ativos e inativos e pensionistas, na forma do regulamento.

Os arts. $4^{\circ}$ e $5^{\circ}$, da Lei $n^{\circ} 10.887 / 2004$, estabelecem a contribuição social do servidor público, ativo e inativo, de qualquer dos Poderes da União, nos seguintes termos:

Art. $4^{\circ}$. A Lei n ${ }^{\circ} 9.783$, de 28 de janeiro de 1999, passa a vigorar acrescida dos seguintes artigos: "Art. $1^{\mathrm{a}}$-A. A contribuição social do servidor público ativo de qualquer dos Poderes da União, incluídas suas autarquias e fundações, para a manutenção do respectivo regime próprio de previdência social, será de $11 \%$ (onze por cento), incidente sobre a totalidade da base de contribuição. $\S 1^{\circ}$ Entende-se como base de contribuição o vencimento do cargo efetivo, acrescido das vantagens pecuniárias permanentes estabelecidas em lei, os adicionais de caráter individual ou quaisquer outras vantagens, excluídas: I as diárias para viagens; II - a ajuda de custo em razão de mudança de sede; III - a indenização de transporte; IV - o salário-família; V - o auxílio-alimentação; VI - o auxílio-creche; e VII - o abono de permanência de que tratam o $\$ 19$ do art. 40 da Constituição, o $\S 5^{\circ}$ do art. $2^{\circ}$ e o $\S 1^{\circ}$ do art. $3^{\circ}$ da Emenda Constitucional n ${ }^{\circ} 41$, de 19 de dezembro de 2003. $\S 2^{\circ} \mathrm{O}$ servidor ocupante de cargo efetivo poderá optar pela inclusão na base de contribuição das parcelas percebidas em decorrência de local de trabalho, do exercício de cargo em comissão ou de função de confiança para efeito de cálculo do benefício a ser concedido com fundamento no art. 40 da Constituição Federal e art. $2^{\circ}$ da Emenda Constitucional n ${ }^{\circ} 41$, de 19 de dezembro de 2003, respeitada, em qualquer hipótese, a limitação estabelecida no $\S 2^{\circ}$ do art. 40 da Constituição Federal. "Art. $5^{\circ}$. Os aposentados e os pensionistas de qualquer dos Poderes da União, incluídas suas autarquias e fundações, contribuirão com $11 \%$ (onze por cento), incidentes sobre o valor da parcela de proventos de aposentadorias e pensões concedidas de acordo com os critérios estabelecidos no art. 40 da Constituição Federal e nos arts. $2^{\circ}$ e $6^{\circ}$ da Emenda Constitucional $\mathrm{n}^{\circ} 41$, de 19 de dezembro de 2003, que supere o limite máximo estabelecido para os benefícios do regime geral de previdência social.

Por sua vez, o art. $6^{\circ}$ da Lei ${ }^{\circ} 10.887 / 2004$, estabelece:

Art. $6^{\circ}$. Os aposentados e os pensionistas de qualquer dos Poderes da União, incluídas suas autarquias e fundações, em gozo desses benefícios na data de publicação da Emenda Constitucional $\mathrm{n}^{\mathrm{o}}$ 41, de 19 de dezembro de 2003, contribuirão com $11 \%$ (onze por cento), incidentes sobre a parcela dos proventos de aposentadorias e pensões que supere $60 \%$ (sessenta por cento) do limite máximo estabelecido para os benefícios do regime geral de previdência social. Parágrafo único. A contribuição de que trata o caput deste artigo incidirá sobre os proventos de aposentadorias e pensões concedidas aos servidores e seus dependentes que tenham cumprido todos os requisitos para obtenção 
desses benefícios com base nos critérios da legislação vigente até 31 de dezembro de 2003.

Ora, a contribuição dos inativos e das pensionistas julgada pelo STF, em que pese o respeito à admiração que se nutre pelos seus membros, gerou discórdia no meio doutrinário, pois somente o Poder Constituinte originário é que poderia modificar direitos adquiridos pelo servidor público, como inclusive defendido pelo Min. Carlos Velloso em sede acadêmica: ${ }^{15}$

1. Se na vigência da lei anterior, o funcionário havia preenchido todos os requisitos para a aposentadoria, não perde o direito adquirido pelo fato de não haver solicitado a concessão (...) 4. Ademais, um direito adquirido por força da Constituição, obra do Poder Constituinte originário, há de ser respeitado pela reforma constitucional do Poder Constituinte instituído, ou de $2^{\circ}$ grau, vez que este é limitado, explícita e implicitamente, pela Constituição.

Sobre a contribuição de aposentados e pensionistas a que alude o art. $4^{\circ}$, da EC $n^{\circ} 41 / 2003$ o STF, julgando a ADIn $n^{\circ} 3.105 /$ DF e a ADIn $3.128 / \mathrm{DF}$, rejeitou a inconstitucionalidade, e permitiu o desconto de $11 \%$ (onze por cento) nos seguintes termos: ${ }^{16}$

O Tribunal concluiu julgamento de ações diretas de inconstitucionalidade ajuizadas pela Associação Nacional dos Membros do Ministério Público - CONAMP e pela Associação Nacional dos Procuradores da República - ANPR contra o art. $4^{\circ}$, da $\mathrm{EC} \mathrm{n}^{\mathrm{o}} 41 / 2003$, que impõe aos servidores públicos aposentados e aos pensionistas, em gozo de benefícios na data de publicação da referida Emenda, bem como aos alcançados pelo disposto no seu art. $3^{\circ}$, a obrigação tributária de pagar contribuição previdenciária com percentual igual ao estabelecido para os servidores titulares de cargos efetivos ("Art. $3^{\circ}$. É assegurada a concessão, a qualquer tempo, de aposentadoria aos servidores públicos, bem como pensão aos seus dependentes, que, até a data de publicação desta Emenda, tenham cumprido todos os requisitos para obtenção desses benefícios, com base nos critérios da legislação então vigente. $\S 1^{\circ} \mathrm{O}$ servidor de que trata este artigo que opte por permanecer em atividade tendo completado as exigências para aposentadoria voluntária e que conte com, no mínimo, vinte e cinco anos de contribuição, se mulher, ou trinta anos de contribuição, se homem, fará jus a um abono de permanência equivalente ao valor da sua contribuição previdenciária até completar as exigências para aposentadoria compulsória contidas no art. 40, $\S 1^{\circ}$, II, da Constituição Federal. $\S 2^{\circ}$ Os proventos da aposentadoria a ser concedida aos servidores públicos referidos no caput, em termos integrais ou proporcionais ao tempo de contribuição já exercido até a data de publicação

\footnotetext{
${ }^{15}$ Velloso, Carlos Mário da Silva. Temas de Direito Público. Del Rey, 1994, p. 448-449.

${ }^{16}$ STF, Rel. p/acórdão Min. Joaquim Barbosa, ADIn n 3.105/DF e ADIn n 3.128/DF, Pleno, julgado em 18.8.2004, Informativo n. 357, 16-20 ago. 2004.
} 
desta Emenda, bem como as pensões de seus dependentes, serão calculados de acordo com a legislação em vigor à época em que foram atendidos os requisitos nela estabelecidos para a concessão desses benefícios ou nas condições da legislação vigente". "Art. $4^{\circ}$ Os servidores inativos e os pensionistas da União, dos Estados, do Distrito Federal e dos Municípios, incluídas suas autarquias e fundações, em gozo de benefícios na data de publicação desta Emenda, bem como os alcançados pelo disposto no seu art. $3^{\circ}$, contribuirão para o custeio do regime de que trata o art. 40 da Constituição Federal com percentual igual ao estabelecido para os servidores titulares de cargos efetivos. Parágrafo único. A contribuição previdenciária a que se refere o caput incidirá apenas sobre a parcela dos proventos e das pensões que supere: I - cinqüenta por cento do limite máximo estabelecido para os benefícios do regime geral de previdência social de que trata o art. 201 da Constituição Federal, para os servidores inativos e os pensionistas dos Estados, do Distrito Federal e dos Municípios; II - sessenta por cento do limite Máximo estabelecido para os benefícios do regime geral de previdência social de que trata o art. 201 da Constituição Federal, para os servidores inativos e os pensionistas da União") - v. Informativo 349. Ressaltou-se, inicialmente, que as contribuições são tributos, sujeitas a regime jurídico próprio, e cuja propriedade decorre da destinação constitucional das receitas e da submissão às finalidades específicas estabelecidas pelo art. 149, da CF, do qual se extrai que as mesmas podem ser instituídas pela União e pelos Estados e Municípios como instrumento de atuação na área social. Daí, por força do disposto no art. 195, da CF, com a redação da época da edição da EC no 41/2003, a atuação estatal nas áreas da saúde, previdência e assistência social, cujos direitos são o conteúdo objetivo da seguridade social, deve ser custeada por toda a sociedade, de forma direta e indireta, nos termos da lei, por meio dos recursos provenientes dos orçamentos dos entes federados e das contribuições sociais previstas nos incisos I a III do referido artigo. Em relação ao caput do art. $4^{\circ}$ da EC n ${ }^{\circ} 41 / 2003$, as ofensas alegadas pelos requerentes foram afastadas por estas razões: a) por serem as contribuições espécie de tributo, não há como opor-lhes a garantia constitucional ao direito adquirido: a.1) a norma que institui ou majora tributos incide sobre fatos posteriores à sua entrada em vigor; a.2) não consta do rol dos direitos subjetivos inerentes à situação de servidor inativo o de imunidade tributária absoluta dos proventos correlatos. Assim, sendo a percepção de proventos de $\begin{array}{llllllllll}\mathrm{a} & \mathrm{p} & \mathrm{O} & \mathrm{s} & \mathrm{e} & \mathrm{n} & \mathrm{t} & \mathrm{a} & \mathrm{d} & \mathrm{O}\end{array}$ rias e pensões fato gerador da contribuição previdenciária (EC n ${ }^{\circ} 41 / 2003$, art. $4^{\circ}$, parágrafo único), não obstante a condição de aposentadoria, ou inatividade, representar situação jurídico-subjetiva sedimentada que, regulando-se por normas jurídicas vigentes à data de sua consolidação, é intangível por lei superveniente no núcleo substantivo desse estado pessoal, não se poderia conferir ao servidor inativo nem ao pensionista verdadeira imunidade tributária absoluta, sem previsão constitucional, quanto aos fatos geradores ocorridos após a edição da EC $n^{\circ} 41 / 2003$, observados os princípios constitucionais da irretroatividade e da anterioridade (CF, art. 150, III, a e art. $\left.195, \S 6^{\circ}\right)$; b) o princípio constitucional de irredutibilidade da remuneração dos servidores públicos não se estende aos tributos porque não implica imunidade tributária; c) a utilização da percepção de proventos como fato gerador da contribuição previdenciária não configura bis in idem de imposto sobre a renda: as contribui- 
ções previdenciárias não constituem imposto. Para discerni-las, além do fato gerador e da base de cálculo, há de se levar em consideração os fatores distintivos constitucionais da finalidade da instituição e da destinação das receitas (CF, arts. 149 e 195). Também não consubstancia bitributação o fato de as contribuições apresentarem a mesma base de cálculo do imposto sobre a renda em relação aos inativos, haja vista a existência de autorização constitucional expressa (CF, art. 195, II); d) a contribuição instituída não se faz sem causa, razão por que não se há de falar em confisco ou discriminação sob o fundamento de que "não atende aos princípios da generalidade e da universalidade

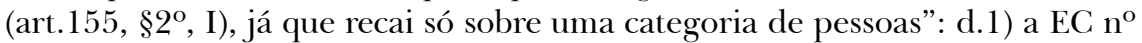
41/2003 transmudou a natureza do regime previdencial que, de solidário e distributivo, passou a ser meramente contributivo e, depois, solidário e contributivo, por meio da previsão explícita de tributação dos inativos, "observados critérios que preservem o equilíbrio financeiro e atuarial”, em face da necessidade de se resolver o colapso havido no sistema, em decorrência, dentre outros fatores, da queda da natalidade, do acesso aos quadros funcionais públicos, do aumento da expectativa de vida do brasileiro e, por conseguinte, do período de percepção do benefício; d.2) o sistema previdenciário, objeto do art. 40 da CF nunca foi de natureza jurídico-contratual, regido por normas de direito privado. $\mathrm{O}$ valor pago pelo servidor a título de contribuição previdenciária nunca foi nem é prestação sinalagmática, mas tributo destinado ao custeio da atuação do Estado na área da previdência social; d.3) o regime previdenciário público visa garantir condições de subsistência, independência e dignidade pessoais ao servidor idoso por meio do pagamento de proventos da aposentadoria durante a velhice e, nos termos do art. 195 da CF, deve ser custeado por toda a sociedade, de forma direta e indireta, o que se poderia denominar princípio estrutural da solidariedade; d.4) o regime previdenciário assumiu caráter contributivo para efeito de custeio eqüitativo e equilibrado dos benefícios, sem prejuízo da observância dos princípios do parágrafo único do art. 194 da CF: universalidade, uniformidade, seletividade e distributividade, irredutibilidade, eqüidade no custeio e diversidade da base de financiamento. Assim, os elementos sistêmicos figurados no "tempo de contribuição", no "equilíbrio financeiro e atuarial" e na "regra de contrapartida" devem ser interpretados em conjunto com os princípios supracitados; e) a cobrança, em si, da contribuição dos inativos não ofende o princípio da isonomia: e.1) o advento da EC n n $^{\circ}$ 41/2003 estabeleceu, em tese, a existência de três grupos de sujeitos passivos distintos: os aposentados até a data da publicação da Emenda (que se aposentaram com vencimentos integrais); os que se aposentarão após a data de sua edição, mas que ingressaram no serviço público antes dela (que, numa fase de transição, poderão aposentar-se com proventos integrais, observadas as regras do art. $6^{\circ}$ da EC $n^{\circ} 41 / 2003$ ); os que ingressaram e se aposentarão após a publicação da Emenda (que poderão, no caso do $\$ 14$ do art. 40 da CF, sujeitar-se ao limite atribuído ao regime geral da previdência - CF, art. 201 - e equivalente a dez salários mínimos); e.2) o fato de já estarem aposentados à data da publicação da Emenda não pode retirar a responsabilidade social pelo custeio, já que seu tratamento previdenciário é diverso do reservado aos servidores da ativa; e.3) o caráter contributivo e solidário da previdência social impede essa distorção, que implicaria ofensa ao princípio da "equidade na forma de participação de 
custeio" (CF, art. 194, IV). De outro lado, em relação ao parágrafo único do art. $4^{\circ}$ da norma impugnada, entendeu-se configurada a violação ao princípio da igualdade por estes fundamentos: a) o fato de alguns serem inativos ou pensionistas dos Estados, do DF ou dos Municípios não legitima o tratamento diferenciado dispensado aos servidores inativos e pensionistas da União, que se encontram em idêntica situação jurídica; b) o fato de ter-se aposentado o servidor antes ou depois da publicação da Emenda não justifica tratamento desigual quanto à sujeição do tributo. Salientou-se que o parágrafo único do art. $4^{\circ}$ da EC n n $^{\circ} 1 / 2003$, ao criar exceção à imunidade prevista no $§ 18$ do art. 40 da CF, com a redação dada pela própria Emenda, faz exceção, da mesma forma, à imunidade do inciso II do art. 195 da CF, aplicável, por extensão, aos servidores inativos e pensionistas, por força da interpretação teleológica e do disposto no $\$ 12$ do art. 40 da CF ("Art. 40. Aos servidores titulares de cargos efetivos da União, dos Estados, do Distrito Federal e dos Municípios, incluídas suas autarquias e fundações, é assegurado regime de previdência de caráter contributivo e solidário, mediante contribuição do respectivo ente público, dos servidores ativos e inativos e dos pensionistas, observados critérios que preservem o equilíbrio financeiro e atuarial e o disposto neste artigo.... §12. Além do disposto neste artigo, o regime de previdência dos servidores públicos titulares de cargo efetivo observará, no que couber, os requisitos e critérios fixados para o regime geral de previdência social.... §18. Incidirá contribuição sobre os proventos de aposentadorias e pensões concedidas pelo regime de que trata este artigo que superem o limite máximo estabelecido para os benefícios do regime geral de previdência social de que trata o art. 201, com percentual igual ao estabelecido para os servidores titulares de cargos efetivos."; "Art. 195. A seguridade social será financiada por toda a sociedade, de forma direta e indireta, nos termos da lei, mediante recursos provenientes dos orçamentos da União, dos Estados, do Distrito Federal e dos Municípios, e das seguintes contribuições sociais:... II - do trabalhador e dos demais segurados da previdência social, não incidindo contribuição sobre aposentadoria e pensão concedidas pelo regime geral de previdência social de que trata o art. 201;"). Diante disso, e considerando o caráter unitário do fim público dos regimes geral de previdência e dos servidores públicos e o princípio da isonomia, concluiu-se que o limite a que alude o inciso II do art. 195 da CF - R $\$ 2.400,00$ (EC n ${ }^{\circ} 41 / 2003$, art. $5^{\circ}$ ) - haveria de ser aplicado a ambos os regimes, sem nenhuma distinção. Julgou-se, por maioria, improcedente o pedido em relação ao caput do art. $4^{\circ}$ da EC $n^{\circ}$ $41 / 2003$. Vencidos, no ponto, os Ministros Ellen Gracie, relatora, Carlos Britto, Marco Aurélio e Celso de Mello que consideravam que a norma impugnada ofendia dispositivos constitucionais que estariam a salvo da atividade reformadora (CF, art. $\left.60, \S 4^{\circ}, \mathrm{IV}\right)$. Declarou-se, por unanimidade, a inconstitucionalidade das expressões "cinqüenta por cento do" e "sessenta por cento do" constantes, respectivamente, dos incisos I e II do parágrafo único do art. $4^{\circ}$ da EC $\mathrm{n}^{\circ} 41 / 2003$, pelo que se aplica, à hipótese do art. $4^{\circ}$ da EC n $n^{\circ} 41 / 2003$, o $\$ 18$ do art. 40 do texto permanente da Constituição, introduzido pela mesma Emenda constitucional.

Pela decisão do STF os $11 \%$, da contribuição previdenciária, inci- 
dirão sobre as parcelas dos benefícios que excederem o valor do teto do regime geral de previdência fixado, em agosto de 2004, em R $\$ 2.508,72$. Pela proposta anterior, a contribuição de $11 \%$ era aplicada sobre as parcelas que excedessem 50\% desse teto nos Estados e Municípios (R $\$ 1.254,23)$, e sobre o que ultrapassasse $60 \%$ do teto, para os servidores da União Federal.

Pela atual fórmula, proposta pelo Min. Cezar Peluso, e aderida por todos os membros do STF, quando dos citados julgados (ADIn n ${ }^{\circ} 3.105 / \mathrm{DF}$ e ADIn no 3.128/DF), o Poder Público terá que devolver a diferença dos valores descontados dos aposentados e pensionistas, em valores superiores nos meses de maio, junho e julho de 2004.

Esta é radiografia dos servidores ativos, inativos e pensionistas até agosto/2004: ${ }^{17}$

No mesmo sentido, vale transcrever recentíssima decisão do eminente e culto Desembargador Federal Sérgio Feltrin Corrêa, do TRF-2 ${ }^{\mathrm{a}}$ Região, ao analisar pleito idêntico ao presente. proposto pelo

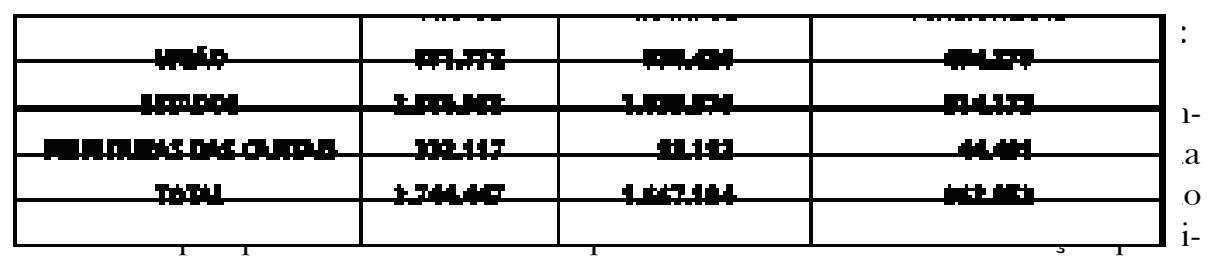

denciária estabelecida pela Emenda Constitucional no 41/2003 e regulamentada pela Medida Provisória $n^{\circ} 167 / 2004$.... (omissis) A questão trazida aos autos cinge-se à possibilidade ou não da cobrança da contribuição previdenciária instituída pela Medida Provisória ${ }^{\circ} 167$, de 19.2.2004, com respaldo no art. $4^{\circ}$ da Emenda Constitucional $n^{\circ} 41 / 2003$, em relação aos servidores públicos já aposentados à época da entrada em vigor da referida norma. De fato, preceitua o inciso XXXVI do art. $5^{\circ}$ da CRFB/88 que "a lei não prejudicará o direito adquirido, o ato jurídico perfeito e a coisa julgada”. Por outro lado, o $\S 4^{\circ}$, inciso IV, do art. 60 da CRFB/88, assim dispõe: "Não será objeto de deliberação a proposta de emenda tendente a abolir: (omissis) IV - os direitos e garantias individuais". Assim, em preliminar análise, parece ocorrente violação às garantias individuais do direito adquirido e ato jurídico perfeito, in casu, pois a exação imposta ao impetrante desrespeita situação jurídica já consagrada, qual seja, a

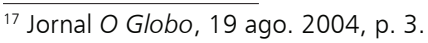

A \& C R. de Dir. Administrativo e Constitucional, Belo Horizonte, ano 5, n. 19, p. 161-199, jan./mar. 2005 
concessão de sua aposentadoria se dá através de ato jurídico complexo efetuado pela Administração, tendo sido incorporado ao seu patrimônio jurídico o direito subjetivo de não pagar contribuição previdenciária. A própria Emenda Constitucional $n^{\circ} 41 / 2003$, em seu art. $3^{\circ}, \S 2^{\circ}$ dispõe que "os proventos de aposentadoria a ser concedida aos servidores referidos no caput, em termos integrais ou proporcionais ao tempo de contribuição já exercido até a data de publicação desta Emenda, bem como as pensões de seus dependentes, serão calculados de acordo com a legislação em vigor à época em que foram atendidos os requisitos nela estabelecidos para a concessão desses benefícios ou nas condições da legislação vigente". Ademais, válido se faz considerar que a contribuição desse modo pretendida impor remete a outro campo, pertinente este ao aspecto de que o ilustre magistrado aposentado, ou ostentando todas as condições a tanto bastantes já implementadas, verteu oportunamente os recursos para assegurar a contraprestação correspondente. Exigir-lhe mais implicaria clara ofensa a cláusulas pétreas, que ao legislador, despido dos indispensáveis poderes, não cabe subverter ou ampliar, a seu talante. Nestes limites, por entender presentes os requisitos do art. $7^{\circ}$, II, da Lei $\mathrm{n}^{\circ} 1.533 / 51$, tenho como merecedora de acolhimento a vigorosa argumentação do Impetrante. Defiro o pedido liminar, para determinar que a ilustre autoridade apontada como coatora ordene medidas bastantes a impedir seja cobrada a aludida contribuição previdenciária sobre os proventos de aposentadoria do impetrante, até definitivo exame da controvérsia pela E. $2^{\text {a }}$ Turma.

Por outro lado, consoante lição do STF quando do julgamento da ADIN n ${ }^{\circ}$ 790/DF, que declarou inconstitucional o art. $9^{\circ}$, da Lei ${ }^{\circ}$ 8.162/91, cujo relator foi o Exmo. Sr. Ministro Marco Aurélio, com o brilhantismo que lhe é peculiar, fixou o Eg. Sodalício que a nova tributação para a Previdência Social, incidentes sobre os proventos dos servidores aposentados, contrariava a regra implícita correspondente ao $\S 5^{\circ}$, do art. 195, da Carta, e também os preceitos dos arts. 149 e 153, II, do referido Diploma Maior:

O custeio da aposentadoria como de responsabilidade do Tesouro Nacional configura, sem dúvida, o desaparecimento da causa das contribuições. Se é certa a existência de plano de seguridade social de que cuida o art. 183, da Lei $n^{\circ} 8.112 / 90$, abrangendo a contribuição aos servidores, impossível é o afastamento do equilíbrio notado entre contribuições e benefícios. No caso, repito, não persistiu, com a derrubada do veto, o móvel majorado da primeira, prevista no art. $9^{\circ}$ da Lei $n^{\circ} 8.162 / 91$. Daí a convicção de que os acréscimos passaram a significar uma tributação adicional sobre a remuneração dos servidores, contrariando a regra implícita correspondente ao $\S 5^{\circ}$, do art. 195, da Carta e, também, os preceitos dos arts. 149 e 153, II, do referido Diploma Maior... sem causa agasalhada pela Constituição Federal implicou a majoração da alíquota relativa à contribuição social dos servidores públicos federais.

Nessa vertente, o STF fixou a impossibilidade de proposta de 
emenda contrária às cláusulas pétreas no RTJ 99/1031:18

Mandado de segurança contra ato da Mesa do Congresso que admitiu a deliberação de proposta de emenda constitucional que a impetração alega ser tendente à abolição da República (Obs.: na vigência da Constituição anterior, a matéria "república" também era cláusula pétrea). Cabimento do mandado de segurança em hipóteses em que a vedação constitucional se dirige ao próprio processamento da lei ou da emenda vedando sua apresentação (como é o caso previsto no parágrafo único do art. 57) ou a sua deliberação (como na espécie). Nesses casos, a inconstitucionalidade diz respeito ao próprio andamento do processo legislativo, e isso porque a Constituição não quer — em face da gravidade das deliberações, se consumadas - sequer se chegue à deliberação proibindo-a taxativamente. A inconstitucionalidade, se ocorrente, já existe antes de o projeto ou de a proposta se transformar em lei ou em emenda constitucional, porque o próprio processamento já desrespeita frontalmente a Constituição.

Entendo que os servidores aposentados e as pensionistas que se inativaram ou adquiriram o aludido benefício antes da EC $n^{\circ} 41 / 2003$ não podem ser sujeitos passivos da contribuição social de inativos, instituída pela citada EC, pois possuem direito adquirido de permanecerem regidos pela legislação vigente à época em que reuniram todas as condições jurídicas exigidas no momento próprio.

Ora, admitir que um direito adquirido seja revisto por um poder constituinte derivado, é o mesmo que afrontar a segurança jurídica, prevalecendo o julgamento político, uma vez que a CF limita, explícita e implicitamente, alterações que visam a desconstituir direitos fundamentais. O Poder Executivo, ao elencar suas prioridades econômicas, não pode dissociar-se dos valores humanos, onde eleitores idosos depositaram nas urnas todas as esperanças de um Brasil melhor. Aliás, a Professora Judith N. Shklar, ${ }^{19}$ da Harvard University Press, já preconizava:

Se o valor dos julgamentos políticos depende da política que promovem, segue-se que os julgamentos políticos dos regimes totalitários são arbitrários não por serem políticos, mas porque promovem atos políticos censuráveis. Ojulgamento dos principais criminosos de guerra em Nuremberg se justificou apenas pelos valores políticos que representou. Que dizer dos julgamentos políticos que ocorrem onde não há regimes totalitários ou numa situação (tal como a da Europa em 1945) em que não predominam a lei e a ordem? Noutras palavras, que dizer dos julgamentos políticos nos sistemas constitucionais estáveis em que os valores e as instituições jurídicas predominam?

\footnotetext{
${ }^{18}$ RTJ, 99/1301

${ }^{19}$ SHKLAR, Judith N. Direito Político e Mora. Tradução de Octavio Alves Velho e Carlos Nayfeld. Forense, 1967, p. 198.
}

A \& C R. de Dir. Administrativo e Constitucional, Belo Horizonte, ano 5, n. 19, p. 161-199, jan./mar. 2005 


\section{Da aposentadoria por invalidez}

O servidor público será aposentado por invalidez permanente, sendo os proventos integrais quando decorrentes de acidente em serviço, moléstia profissional ou doença grave, especificada em lei e proporcionais nos demais casos (aposentadoria compulsória e aposentadoria voluntária).

Constatação de moléstia grave deve ser precedida de perícia médica: ${ }^{20}$

Administrativo. Servidor público. Aposentadoria por invalidez. Moléstia grave. Neoplasia maligna comprovada. Art. 186, I, $\S 1^{\circ}$, da Lei $\mathrm{n}^{\circ}$ 8.112/90. Perícia médica. 1. Extinção do processo que se afigura precipitada. Recomendável a perícia médica para adequada solução da lide, não obstante ser a apelante portadora de moléstia grave. 2. Apelação provida.

\section{Aposentadoria por invalidez permanente: ${ }^{21}$}

Administrativo. Servidor público. Aposentadoria por invalidez permanente. Art. 186, inc. I, $\S 1^{\circ}$, combinado com art. 40 , inc. I, da $\mathrm{CF} / 88$. Vantagem de que trata o art. 192, inc. II, da Lei $\mathrm{n}^{\circ} 8.112 / 90$. Possibilidade. 1. Tendo o demandante se inativado com fulcro no art. 186, inc. I, da Lei $\mathrm{n}^{\circ}$ 8.112/90, pela modalidade da aposentadoria por invalidez, para percepção da vantagem, prevista no art. 192, inc. II, da Lei $\mathrm{n}^{\circ} 8.112 / 90$, não há falar em exigência de tempo de serviço de que trata o art. 186, inc. III, da referida Lei, tendo em vista que diz respeito à modalidade da aposentadoria voluntária. 2. A condição que levou o demandante à inativação por invalidez é um fato e nesse caso a legislação socorre com a concessão de provento integral, como se o inativado houvesse laborado pelo efetivo tempo de serviço. Não pode ser a aposentadoria por invalidez uma penalização ao servidor, mas sim uma forma de reconhecimento de que seu trabalho prestado e o que viria a prestar equivaleria ao de um trabalho efetivado por um servidor da ativa. 3. Reconhecimento do direito do autor à vantagem prevista no art. 192, inc. II, da Lei $\mathrm{n}^{\circ} 8.112 / 90$.

Moléstia grave e pagamento integral da aposentadoria por invalidez: ${ }^{22}$ Administrativo. Servidor público. Invalidez. Moléstia grave. Especificação em lei. Aposentadoria. Proventos integrais. 1. Comprovada a existência de doença grave, especificada em lei, os proventos da aposentadoria deverão ser integrais. 2. Recurso provido.

Aposentadoria por invalidez e recebimento de proventos proporcionais: ${ }^{23}$

\footnotetext{
20 TRF-1 ${ }^{\text {a }}$ Reg., Rel Des. Fed. Luiz Gonzaga Barbosa Moreira, Ap. Cível nº 2001.34. 00011270-5/DF, $1^{\text {a }}$ T., DJ de 20.10.2003, p. 19.

${ }^{21}$ TRF-4a Reg., Rel. Des. Fed. Sérgio Renato Tejada Garcia, Ap. Cível 306679/PR, 4a T., DJ de 21.8.2002, p. 769.

${ }_{22}$ STJ, Rel. Min. Fernando Gonçalves, ROMS n 10.936/MG, 6a T., DJ de 1.4.2002, p. 62.
} 
Administrativo. Servidor. Aposentadoria por invalidez. Incapacitação. Art. 186, $\S 1^{\circ}$, da Lei 8.112/90. Art. 40, I, da CF. I. Nos termos do art. 186 da Lei $\mathrm{n}^{\mathrm{o}}$ $8.112 / 90$, a aposentadoria por invalidez com proventos integrais, ainda que grave, incapacitante e incurável seja a doença sofrida pelo servidor — Epidermólise Bolhosa Distrófica - não será, in casu, devida, por essa moléstia não se encontrar elencada no $\S 1^{\circ}$ do referido artigo. II. Se não houver especificação, os proventos serão proporcionais.

No mesmo sentido: STJ - Rel. Min. Felix Fischer, REsp n ${ }^{\circ}$ 216.773/ SC, $5^{\text {a }}$ T., $D J$ de 2.5.2000, p. 161).

Impossibilidade de acumulação da aposentadoria por invalidez de servidor público com os proventos percebidos pelo INSS: ${ }^{24}$

Administrativo e constitucional. Recurso ordinário em mandado de segurança. Aposentadoria por invalidez. Servidor público. Proventos percebidos pelo INSS. Acumulação. Impossibilidade. I. É vedada a acumulação de proventos e vencimentos quando os cargos, funções ou empregos são inacumuláveis. II. In casu, a situação irregular advinda da percepção cumulativa de proventos e vencimentos, não se estende à inatividade, sendo impossibilitada a concessão de nova aposentadoria. Precedentes desta Corte e do Colendo STF. Recurso provido.

\section{Reversão para a ativa do aposentado por invalidez: ${ }^{25}$}

Administrativo. Servidor público. Reversão. Aposentadoria por invalidez. Arts. 25 a 27 da Lei $n^{\circ} 8.112 / 90$. Ausência. Infringência. 1. O servidor público aposentado por invalidez, cessada a causa da aposentação antes dos 70 anos de idade, tem direito à reversão para o mesmo cargo, ou para aquele em que se tenha transformado, ou, ainda, para cargo de vencimento ou remuneração e atribuições equivalentes ao anteriormente ocupado, observado o requisito da habilitação profissional. 2. Recurso não conhecido.

Plano de demissão voluntária de servidor portador de vírus da AIDS, cometido por cirrose hepática e amputação da perna, anulação do ato administrativo de desligamento: ${ }^{26}$

Administrativo. Plano de demissão voluntária. Servidor portador de vírus da AIDS, cometido por cirrose hepática e amputação de perna. Anulação do ato administrativo. Vício de ilegalidade. Art.186, I, $\S 1^{\circ}$ da Lei $\mathrm{n}^{\circ} 8.112 / 90$ e art. $2^{\circ}$, VI, Lei $n^{\circ} 9.468 / 97$. Ausência de discernimento das conseqüências de seus

\footnotetext{
${ }^{23}$ STJ, Rel. Min. José Arnaldo da Fonseca, MS n 8.334/DF, Corte Especial, DJ de 19.5.2003, p. 107.

${ }^{24}$ STF, Rel. Min. Felix Fischer, ROMS no 15.440/PB, 5a T., DJ de 23.6.2003, p. 365

25 STJ, Rel. Min. Fernando Gonçalves, REsp n 199.277/RJ, 6 ${ }^{\mathrm{a}}$ T., DJ de 13.9.1999, p. 120.
} 
atos. Juros de mora. Remessa cabível, embora não consignada (Lei no 9.469/97). - A alegação da ré de que não tinha conhecimento da doença do servidor não é suficiente para não ser julgado procedente o pedido, diante das provas dos autos. Ao revés, comprovados gravíssimos problemas de saúde (resultado de AIDS, tratamento de desintoxicação, hepatite crônica, acidente automobilístico, amputação de perna, nascimento da filha, tratamento psiquiátrico) por que passava o servidor, caracterizando estado desesperador, vê-se que não possuía condições plenas para avaliar as conseqüências de sua adesão ao PDV, notadamente quando refere-se ao próprio sustento e de sua família. -Impõe-se a anulação do ato administrativo que, na espécie, refere-se à Portaria $n^{\circ} 1.090$, de 12.12.1996, que exonerou o servidor por adesão ao Plano de Demissão Voluntária, vez que eivado de ilegalidade, seja porque prevista na Lei no $8.112 / 90 \mathrm{e}$ na Lei $n^{\circ}$ 9.468/97 a exclusão dos servidores em estado como o sub examine para aderir ao PDV, fazendo jus à aposentadoria por invalidez, seja porque a prática do ato se deu por pessoa que não tinha plena capacidade de discernimento das conseqüências do mesmo (CC, art. 83). -A restituição dos valores recebidos a título de adesão ao PDV por parte da autora deve observar o disposto no art. 46 da Lei n ${ }^{\circ} 8.112 / 90$, que "deverão ser comunicadas ao servidor ou ao pensionista e amortizadas em parcelas mensais cujos valores não excederão a dez por cento da remuneração ou provento", valendo ressaltar, ainda, o caráter alimentar dos valores, não havendo falar em compensação automática, como requer a Autarquia-Apelante. - Os juros de mora, em se tratando de débitos de natureza alimentar, devem ser contados a partir da citação válida (STJ, REsp n ${ }^{\circ} 311.907 /$ RN, Rel. Min. Fernando Gonçalves, DJ de 13.8.2001; REsp nº 302.099/CE, Rel. Min. Felix Fischer, DJ de 9.4.2001). -Recurso e remessa parcialmente providos apenas para reformar a sentença no tocante à fixação dos juros de mora, que devem ser computados a partir da citação válida, mantendo-a inalterada quanto aos demais aspectos.

Cardiopatia grave e direito à integralidade da gratificação de chefia: ${ }^{27}$

Administrativo. Servidor público. Aposentadoria. Cardiopatia grave. Proventos. Dedicação exclusiva. Gratificação de chefia. Direito à integralidade. Exigência de submissão à junta médica. Desnecessidade. Termo de compromisso. Inaplicabilidade. 1. O inc. I, do art. 186, da Lei $\mathrm{n}^{\circ} 8.112 / 90$ estabelece que o servidor será aposentado por invalidez com proventos integrais quando a invalidez for decorrente de doença grave. 2. A cardiopatia grave se encontra elencada no $\S 1^{\circ}$ do art. 186. 3. A Medida Provisória n ${ }^{\circ}$ 1.573-9/97 não alcança atos anteriores a sua vigência. 4. A integralidade corresponde à remuneração que percebia o servidor quando estava em atividade antes de ser acometido da moléstia que o invalidou. 5. O Termo de Compromisso somente vigora quando se tratar de aposentadoria voluntária.

\footnotetext{
${ }^{26}$ TRF-2 ${ }^{a}$ Reg., Rel. Des. Fed. Benedito Gonçalves, Ap. Cível n 259.431/ES, 4ª T., DJ de 4.4.2002, p. 369.

${ }^{27}$ TRF-4a Reg., Rel. Des. Fed. Luiza Dias Cassales, Ap. Cível nº 171.137/RS, 3a T., DJ de 17.11.1999, p. $204 / 205$.
}

A \& C R. de Dir. Administrativo e Constitucional, Belo Horizonte, ano 5, n. 19, p. 161-199, jan./mar. 2005 
Aposentadoria por invalidez é a passagem do servidor em atividade para a inatividade, com proventos integrais ou proporcionais, por estar incapacitado para o serviço público.

O requisito básico para a concessão do benefício sub oculis é a incapacidade do servidor público vir atestado por Junta Médica oficial.

São os seguintes os documentos básicos que devem constar no requerimento da aposentadoria por invalidez: laudo médico fornecido pela Junta Médica oficial; declaração de bens e valores ou cópia da declaração do imposto de renda e declaração de dependentes.

O servidor será aposentado por invalidez permanente, sendo os proventos integrais, quando decorrente de acidente em serviço, moléstia profissional ou doença grave, contagiosa ou incurável, especificada em lei, e proporcionais, nos demais casos.

Consideram-se doenças graves, contagiosas ou incuráveis, tuberculose ativa, alienação mental, esclerose múltipla, neoplasia maligna, cegueira posterior ao ingresso no serviço público, hanseníase, cardiopatia grave, doença de Parkinson, paralisia irreversível e incapacitante, espondiloartrose aniquilante, nefropatia grave, estados avançados do mal de Paget (osteíte deformante), Síndrome de Imunodeficiência Adquirida - AIDS, e outras que a lei indicar, com base na medicina especializada.

É considerado acidente em serviço o evento causador de dano físico ou mental que tiver como causa imediata ou remota o exercício das atribuições inerentes ao cargo.

Equipara-se ao acidente em serviço à agressão sofrida e não provocada pelo servidor no exercício do cargo, ainda que fora do local de trabalho, bem como o dano sofrido no percurso da residência para o trabalho e vice-versa.

O servidor poderá provar, em processo administrativo especial, no prazo de 10 dias, prorrogável quando as circunstâncias o exigirem, que o acidente deu-se no serviço.

\section{Emenda Constitucional n 41/2003 e o respeito aos direitos adquiridos}

Mesmo estabelecendo a EC $n^{\circ} 41 / 2003$, pelo seu art. $3^{\circ}$, o respeito ao direito adquirido de aposentadoria aos servidores públicos, bem como pensão aos seus dependentes, que tenham reunido, até a data da sua publicação, os requisitos eleitos pela legislação anterior, os novos textos

A \& C R. de Dir. Administrativo e Constitucional, Belo Horizonte, ano 5, n. 19, p. 161-199, jan./mar. 2005 
legais poderão trazer situações ilegais.

O certo é que a discussão jurídica sempre elevada quando se constata que o constituinte derivado infringiu a limitação de reformar o Texto Mater, a teor do dispositivo contido no art. $60, \S 4^{\circ}$, IV, da CF, não poderia violar direitos fundamentais, contidos no art. $5^{\circ}$ da mesma Lei Maior, dentre eles o direito adquirido.

Assim, qualquer violação a direitos adquiridos podem ser questionados perante o Judiciário, pois como muito bem averbou o Min. Carlos Velloso, o Poder constituinte de $2^{\mathrm{a}}$ grau (derivado) deve respeitar um direito adquirido por força da Constituição, obra do Poder constituinte originário: ${ }^{28}$

4. Ademais, um direito adquirido por força da Constituição, obra do Poder constituinte originário, há de ser respeitado pela reforma Constitucional, produto do Poder Constituinte instituído, ou de $2^{\circ}$ grau, vez que este é limitado, explícita e implicitamente, pela Constituição.

Na ADIn no 829/DF, Pleno, STF, DJ de 16.9.1994, p. 24.278, o Min. Carlos Velloso proferiu precioso voto sobre o respeito da dicotomia entre o Poder Constituinte originário e o Poder Constituinte derivado:

A doutrina das constituições rígidas distingue, a partir do surgimento da idéia de poder constituinte, que é contemporânea da idéia da Constituição, e que veio a lume com o discurso de Siyès, publicado em 1788, intitulado Qu'est-ce que lê Tiers État?, o Poder Constituinte originário do Poder Constituinte derivado, assim estabelecendo, registra o Professor Pinto Ferreira, com base na obra do abade Sieyès, "a dicotomia entre potestas constituens e potestas constituta, o poder de reforma devendo atuar nos termos expressamente previstos na Constituição" (Pinto Ferreira, 'O problema da revisão constitucional e seus limites. Estudos constitucionais', OAB, Simpósio sobre revisão e plebiscito, Brasília, 1992, p. 186). Essa doutrina que estabelece limites à ação do poder constituinte constituído, eu próprio a examinei e divulguei em trabalho publicado no ano de 1972 - "Funcionário público. Aposentadoria. Direito adquirido. RDP 21/174 - e pode ser lida em autores da maior suposição: C. Schmitt, Hauriou, Karl Loewenstein, Recaséns Siches, George Burdeau, Bernard Schwartz, Jorge Miranda, Gomes Canotilho, Rui Barbosa, Manoel Gonçalves Ferreira Filho, Raul Machado Horta, Oswaldo Aranha Bandeira de Mello, Nelson de Souza Sampaio, Rosah Russomano, Pinto Ferreira, Geraldo Ataliba, José Afonso da Silva, Carmem Lúcia Antunes Rocha, Celso Bastos, Miguel Temer, José Alfredo de Oliveira Baracho, Afonso Arinos de Mello Franco, Paulo Bonavides, Paulino Jacques, Celso Antônio Bandeira de Mello, Geraldo Brindeiro, dentre outros. O Poder Constituinte originário é inicial e ilimitado, enquanto o Poder Constituinte derivado é um poder secundário, subordinado à Constituição, que lhe impõe limi-

${ }^{28}$ VELlOSO, Carlos Mário da Silva. Temas de Direito Público. Del Rey, 1994, p. 448-449.

A \& C R. de Dir. Administrativo e Constitucional, Belo Horizonte, ano 5, n. 19, p. 161-199, jan./mar. 2005 
tes. Aquele cria a Constituição, este simplesmente a reforma. Daí a conclusão no sentido de que a revisão é constituída pela Constituição. Na verdade, o poder de reforma constitucional não passa de um poder constituído, ou é o próprio Poder Legislativo, que é poder constituído, registrei no trabalho doutrinário que escrevi e que está acima indicado ( $R D P$ 21/174, 178). Canotilho leciona que "o poder de revisão constitucional é, conseqüentemente, um poder constituído tal como poder legislativo. Verdadeiramente, o poder de revisão só em sentido impróprio se poderá considerar constituinte; será, quando muito "uma paródia do poder constituinte verdadeiro" (Canotilho, J.J. Gomes, Direito constitucional, $5^{\mathrm{a}}$ ed., Coimbra: Almedina, 1991, p. 99). O Poder Constituinte derivado, porque limitado pela obra do Poder Constituinte originário, assim limitado pela Constituição, há de agir, escrevi no trabalho já indicado, com observância das limitações que lhe são impostas, expressas e implícitas. Consulte-se, a propósito destas últimas, Karl Loewenstein (Teoria de la Constitución. $2^{\mathrm{a}}$ ed., Barcelona: Ariel, p. 189). As limitações expressas são classificadas em limitações materiais, circunstanciais e temporais. Essas limitações, no Brasil, são denominadas cláusulas pétreas. Os constitucionalistas europeus falam em limitações materiais, circunstanciais e temporais. No Brasil a metáfora pegou: cláusulas pétreas. Na Constituição Brasileira, as limitações expressas, circunstanciais e materiais estão inscritas nos $\S \S 1^{\circ}$ e $4^{\circ}$ do art. 60 . Ao lado das cláusulas pétreas, ou das limitações expressas, materiais, circunstanciais e temporais, há outras normas constitucionais que se põem a cavaleiro da reforma. Registra a professora Cármem Lúcia Antunes Rocha que, "de toda sorte, o que parece induvidoso é que, ao lado das cláusulas pétreas expressas no sistema constitucional, as Constituições estabelecem um conjunto de normas intangíveis à mão do reformador ou revisionista da Lei Magna. Entre estas, a doutrina e a jurisprudência constitucionais afirmam, exatamente, aquelas que se referem ao próprio limite formal (data, modo e circunstância de atuação) imposto ao órgão ou agente encarregado da revisão ou reforma. Qualquer atuação que desborde de tal limite eiva-se de inconstitucionalidade e não se impõe ao sistema, devendo ser dele expurgado ou nele impedido o seu ingresso pelos instrumentos processuais próprios a indagar da inconstitucionalidade" (Rocha, Cármen Lúcia Antunes. 'Revisão constitucional e plebiscito. Estudos constitucionais'. OAB. Simpósio sobre Revisão e Plebiscito, Brasília, DF, 1992, p. 49). Os arts. $2^{\circ}$ e $3^{\circ}$ do ADCT não podem ser alterados pelo Poder constituído, porque se referem ao próprio limite formal, contém matéria relativa ao processo de revisão. As matérias relativas ao processo de emenda ou de revisão são intangíveis, não podem ser alteradas pelo poder de revisão, que é poder constituído.

Karl Loewenstein ${ }^{29}$ também adverte que determinadas cláusulas constitucionais se sustentam a Emendas, por meio de uma proibição jurídico-constitucional:

Disposiciones intangibles. Bastante más importancia han adquirido recientemente las llamadas disposiciones intangibles de una constitución, que tienen como fin librar radicalmente de cualquier modificación a determinadas normas constitucionales. Aquí hay que distinguir, por lo pronto, dos situaciones de hecho por una parte, medida para proteger concretas situaciones constitucio- 
nales - intangibilidad articulada - y, otra parte, aquellas que sirven para garantizar determinados valores fundamentales de la constitución que no deben estar necesariamente expresados en disposiciones o en instituciones concretas, sino que rigen como "implícitos", "inmanentes" o "inherentes" a la constitución. En el primer caso, determinadas normas constitucionales se sustraen a cualquier enmienda por medio de una prohibición jurídico-constitucional, y, en el segundo caso, la prohibición de reforma se produez a partir del "espíritu" o "telos" de la constitución, sin una proclamación expresa en una proposición jurídico-constitucional.

Portanto, basta o servidor ou a pensionista demonstrar que houve violação a direito adquirido anteriormente conquistado para que o Judiciário possa frear desmandos ou violações à cláusula pétrea citada.

Entendo, por exemplo, que um servidor aposentado, recebendo a integralidade de seus proventos, com base na paridade com o cargo ativo, ao falecer, sua pensionista não poderá ter diminuição nos respectivos proventos, pois este é imutável por já ter sido implementada as condições quando da concessão do benefício. Assim, a dependente terá que receber o pagamento integral da pensão, sem reduções ou aplicações da nova regra introduzida pela $\mathrm{EC}^{\circ} 41 / 2003$, tendo em vista que mesmo ocorrendo o falecimento em data posterior a publicação da EC citada, a aposentadoria já era integral e a pensionista possuía o direito adquirido de recebê-la sem cortes ou reduções, imunes a criação de normas futuras.

\section{Principais mudanças na PEC Paralela - Proposta de Emenda à Constituição n 227-A, de 2004}

A proposta de Emenda à Constituição no 227-A/2004, mais conhecida como PEC paralela de Reforma da Previdência, foi aprovada pela Câmara dos Deputados em agosto/2004. Ela altera a EC n ${ }^{\circ} 41 / 2003$, para assegurar aos servidores públicos que se encontravam em exercício na data da publicação da aludida Emenda (19 de dezembro de 2003), a possibilidade de se aposentarem com proventos integrais, calculados com base na remuneração do cargo efetivo do servidor, mantendo a regra de paridade, desde que cumprindo condições de tempo de contribuição e de idade, que ultrapassar a mínima de 35 anos para homens e 30 anos para mulheres, como se demonstrará.

A paridade reverte-se de uma dupla vantagem ao servidor, pois assegura a revisão dos proventos, na mesma proporção e na mesma data,

${ }^{29}$ LOEWNSTEIN, Karl. Teoria de la Constitución. 2. ed., Barcelona: Ariel, 1970, p. 189.

A \& C R. de Dir. Administrativo e Constitucional, Belo Horizonte, ano 5, n. 19, p. 161-199, jan./mar. 2005 
sempre que se modificar a remuneração dos servidores em atividade. Permite, também essa situação jurídica que aposentados e pensionistas recebam quaisquer benefícios ou vantagens posteriormente concedidos aos servidores em atividade.

Para ser destinatário da regra paritária, o art. $5^{\circ}$ da PEC no 227-A/04, estipula: "Art. $5^{\circ}$ Ressalvado o direito de opção à aposentadoria pelas normas estabelecidas pelo art. 40 da Constituição Federal, ou pelas regras estabelecidas pelos art. $2^{\circ}$ e art. $6^{\circ}$ da Emenda Constitucional $n^{\circ} 41$, de 2003, o servidor da União, dos Estados, do Distrito Federal e dos Municípios, incluídas suas autarquias e fundações, que tenha ingressado no serviço público até a data da publicação desta Emenda poderá aposentar-se com proventos integrais, aplicando-se o disposto no art. $7^{\circ}$ da Emenda Constitucional $\mathrm{n}^{\mathrm{o}} 41$, de 2003, desde que preencha, cumulativamente, as seguintes condições: I - trinta e cinco anos de contribuição, se homem, e trinta anos de contribuição, se mulher; II - vinte e cinco anos de efetivo exercício no serviço público, quinze anos de carreira e cinco anos no cargo em que se der a aposentadoria; III - idade mínima resultante da redução, relativamente aos limites do art. 40, §1 ${ }^{\circ}$, inciso III, alínea “a”, da Constituição Federal, de um ano de idade para cada ano de contribuição que exceder a condição prevista no inciso I deste artigo".

Por essa regra de paridade todos os servidores públicos que tenham ingressado no serviço público até 31.12.2003, e preencherem as exigências para aposentadoria integral (35 ou 30 anos de contribuição, se homem ou mulher, 60 ou 55 de idade, 20 anos de serviço público, sendo dez na carreira e cinco no cargo) são destinatários dessa regra igualitária com a remuneração recebida em atividade. Dessa forma, é estendida a paridade plena a que alude $\mathrm{o}$ art. $7^{\circ}$ da $\mathrm{EC} \mathrm{n}^{\circ} 41 / 2003$, aos servidores que se aposentarem com base no art. $6^{\circ}$ da própria EC ${ }^{\circ} 41 / 2004$.

A PEC paralela excluiu as parcelas indenizatórias do teto remuneratório, alterando a regra do inc. XI do art. 37 da CF, retirando a expressão "ou de qualquer outra natureza". A retirada desta expressão evita a interpretação de que o pagamento de verbas indenizatórias está sujeito ao teto $(\mathrm{R} \$ 19.115,19)$.

A aposentadoria compulsória para os professores de instituição pública de grau superior, passa de 70 para 75 anos.

Permite também a PEC paralela a adoção de critério diferenciado para a concessão de aposentadoria aos servidores portadores de deficiência, através de Lei Complementar. Alteração proposta alteraria o $\S 4^{\circ}$ do art. 
40 da CF, passando a ter a seguinte redação que permite a aposentadoria especial:

$\S 4^{\circ}$ É vedada a adoção de requisitos e critérios diferenciados para a concessão de aposentadoria aos abrangidos pelo regime de que trata este artigo, ressalvados os casos de atividades exercidas exclusivamente sob condições especiais que prejudiquem a saúde ou a integridade física e os de servidores portadores de deficiência, definidos em lei complementar.

O $\$ 22$ do art. 40 da CF, pela proposta em tela, garante ao aposentado ou a pensionista com doença incapacitante, que somente pagará contribuição sobre a parcela que ultrapasse o valor de $\mathrm{R} \$ 4.800,00$.

O $\$ 10$ do art. 144 da CF, por essa nova proposta, estabelece que o regime previdenciário dos servidores policiais será objeto de lei específica, nos termos que se seguem: "Art. 144. (...) §10. Às aposentadorias e pensões dos servidores policiais que integram órgãos com funções de polícia judiciária, rodoviária e ferroviária da União e de polícia judiciária dos Estados e do Distrito Federal aplica-se o que for fixado em lei específica do respectivo ente federado".

Fixa também valor mínimo para os subsídios dos governadores em $50 \%$ do valor recebido por Ministro do STF.

A PEC paralela tenta suavizar a EC n ${ }^{\circ} 41 / 2003$, facilitando algumas situações jurídicas, em prol do interesse público. Uma delas é a regra de transição, que possibilita ao servidor que ingressou no serviço público até 16 de dezembro de 1998 se aposentar integralmente e com paridade plena antes da idade mínima exigida na Emenda Constitucional $n^{\circ} 41 / 2003$, desde que comprove tempo de contribuição acima do exigido (30 anos para a mulher e 35 para o homem). Assim, para cada ano que o servidor exceder no tempo de contribuição poderá reduzir ou abater um ano na idade mínima. Exemplo: Homem 36/59; 37/58; 38/57; 39/56 e 40/55 etc. Nessas simulações o servidor, todavia, terá que comprovar 25 anos de serviço público, sendo que desse tempo 15 deverão ser na carreira e dez no cargo. ${ }^{30}$

Informação bibliográfica deste texto, conforme a NBR 6023:2002 da Associação Brasileira de Normas Técnicas (ABNT):

MATTOS, Mauro Roberto Gomes de. Aposentadoria dos servidores públicos federais após as reformas da Constituição. A $\mathcal{E}^{2} C$ Revista de Direito Administrativo e Constitucional, Belo Horizonte, ano 5, n. 19, p. 161-199, jan./mar. 2005.

A \& C R. de Dir. Administrativo e Constitucional, Belo Horizonte, ano 5, n. 19, p. 161-199, jan./mar. 2005 


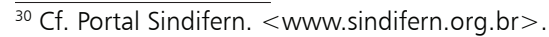

A \& C R. de Dir. Administrativo e Constitucional, Belo Horizonte, ano 5, n. 19, p. 161-199, jan./mar. 2005 